\title{
ARTIGOS
}

\section{A IDEALIZAÇÃO DE ROMA E SUA ACEITAÇÃO PELOS CRISTAOOS}

(Continuação)

\section{CAPITULO II}

\section{ROMA COMO CORPORIFICAÇÃO DO MAL NA LITERATURA SIBILINA E APOCALIPTICA}

Ainda aqui, na questão referente às Idades do mundo, enccntramos material impcrtante nos oráculos sibilinos, mas sem que se lhes possa atribuir - na medida dos nossos conhecimentos -, a primazia da idéia no mundo mediterrâneo. De fato, tal primazia parece caber ao poeta Hesiodo, que, no seu poema "Os trabalhos e os dias" (1), teria pcpularizado o mito das quatro Idades, simbolizando por um metal a decadência progressiva da Humanidade: a do ouro, caracterizada pela vida feliz, sob o govêrno de Cronos; a da prata, já manchada pele impiedade; a do bronze, em que os homens teriam como grande objetivo a guerra; e a do ferro, durante a.qual a Humanidade, alheia a qualquer noção de Justiça, deveria sofrer a opressão dos maus e dos poderosos. $\mathbf{E}^{\prime}$ verdade que, além de Hesiodo, os oráculos sibilincs pagãos também tratavam da dívisão da história do mundo em Idades, váriando entretanto - número destas, de 4 a 12; se bem que não tenhamos o texto de tais oráculos, possuimos os comentários de Sérvio e de Probo às obras de Virgílio, em que tais autores referem-se respectivamente

(1). - Vv. 100-201. Cf. Jeanmaire, "Le messianisme de Virgile", pag. 8 as.: Primm, "Seltsanie Heilandspropheten", pág. 629: Carcopino, "Virglle et le myztzre de la IV." ecologue", pág. 37; Rehm, "Der Untergang Roms", pág. is: Hild, art. "Saeculum" in "Dictionnaire des antiquités Grecques et Romaines" de Daremberg \& Saglio. Zielinski desliga completamente tal mito de tudo quanto yossa ser relacionado com a Sibila, dízendo tratar-se de uma "Hégende deg eibules", diferente e talvez mesmo independente da sibila: "C'eat la celebre légende des 4 ou 5 ages d'Hésiode. Quatre ou cinq. En effet, la progtession logique des quatre âges d'or, d'argent, de bronze et de fer est chez lui interrompue par une cinquième, l'age des héros. Mais puisque déjả l'Antiquité s'est débar. rassée de cet intrus, soit en l'identifiant avec l'àge de bronze soit en l'elliminant tout a fait, nous avons d'autant plus de droit de le négliger nous aussi" ("La Sibylle", págs. 104-105); Cf. Gutbrie, "The Greelss and their Gods", pág. 298. Quanto à importáncia de Hesiodo para o assunto, 6 ela ressaltada sobremaneira por Kirby F. Smith, que assim se expressa: "The account of the Ages which we find in his "Works and Days" (109-201) is our earliest classical authority upon the subject. It is, also, to a remarkable extent, the centre and ultimate source of the later development. There were steveral other accounts of the early history of man, and some of them where evidently lolk-legends of a high antiquity. None of them, however, is of any great importance to us" (Art. "Ages of the World", in "Encyclopedia of Relizion and Ethics"). 
a 10 a 4 Idades (2). De qualquer maneira, porém, a vantagem permaneceria com Hesiodo, uma vez que os oráculos deveriam tratar sempre de prediçóes relativas "a acontecimentos políticos ou a catástrofes de impérios, mas sem referência precisa a uma concepção getal do desenvolvimento do universo e de seu futuro (3). $\mathrm{Na}$ melhor das hipóteses, seriamos levados a procurar al resposta para o problema de se saber quando a Sibila alargou seus horizontes a tôda a história do mundo no que nos diz Cercopino: "um oráculo sibilino - teria sido o que ordenou, em 249 a. C., a fundação dos ludi saeculares? - é possivel, mas indemonstrável, dividiu a história do universo em uma série de Idades distintas ou saecula, sendo cada uma designada pelo nome de um metal e colocada sob o signo do deus celeste que deveria presidir o seu desenvolvimento (4)". Assim, a diferença seria bem grande a favor de Hesíodo, que viveu por volte de $700 \mathrm{a}$. C. De qualquer modo, entretanto, nota-se um traço de concordância entre todos êstes sistemes de divisão da história do mundo: é que, em lugar de haver - desenvolvimento de uma idéia de progresso, há - ao contrário - a descrição das etapas de uma verdadeira decadência, o que leva a estabelecer a primeira Idade como a melhor de tôdss, simbolizada pelo curo, durante a qual teria vivido sôbre a terra, governando os homens, Dikè - a Justiça - "presidindo os conselhos dos Anciãos na preça pública ou nas encruzilhadas campestres, formulando sentenças de Direito e estreitamente associada às fainas agricolas, para as quais assegurava ela a justa recompensa (5). A Idade do Ouro estaria, portanto, num passado remoto e - conforme note Jeanmaire (6), - nem Hesiodo nem Arato (em grande voga em Roma na' época de Virgilio) (7), fazem referência à possibilidade de sue volta (8). Se procurarmos investigar uma outra fonte que pudesse ter contribuido para o desenvolvimento de idéias destá espécie em Roma, iremos ençontrar também êste último traço, que julgamos poder chamar de "irrevogabilidade do Destino"; assim, verificaremos, entre os etruscos, que "a' doutrina da prorrogação decenal serve também para êstes períodos ou séculos; mas, no todo, eram concedidos dez séculos, passados os quais a Etrúria, como tôdas as outras naçōes, deveria desaparecer: quibus

(2). - Carcopino, "Virgilie et le mystère de la IV. ecloque", pág. 38-39. E o teguinte o texto de Servio: "(Carminis) Sibyllini, quae Cumana fuit et rgecula per metalla divisit etiam quis que saeculo imperaret et Solis ultimum, id est, dacimum, voluit" (ap. Jcanmaire, "La Sibylle et le retour de l'age d'or". Dág. 1(0). A respeito das sibilas pagās, em geral, veja-se o trabalho de Prümm. "Seltsame Heilandspropheten".

(3). - Jeanmaire, "La Sibyne", pag. VIII

(4). - Op. cit., pag. 38.

(5). - Arato, "Phaenomena", 112-113, ap. Jeanmatre, "La Sibylle", pag. 2 ;

cr. Lúcken, "Die Sibyllinischen Weissagungen". pAg. 17-18.

(6). - "La sibylle". pág. 3.

(7). - Carcopino, op. cit. pag. 151.

(8). - Lagrange, entretanto, é de opinião que Hesiodo não exclui a possiLilliade do retorno da Idade do Ouro, baseando-se na interpretaça do verso 175 d"Os. Trabelhos e os Dias" ("Le pretendu Messianisme de Virglie", pags. 561,563 e 584). 
transactis finem fore nommis Etrusci (Cen., 17, 6); isto é: até o décimo século poderiam ser desviadas as ameaças do Destina, por meio de expiações, mas, uma vez passado êste século, tôda e qualquer expicição seria inútil (9)".

Teríamos assim, com Hesíodo, com a Sibila e com os etruscos, três fontes de predições aparentadas que, combinadas, poderiam ter resultado no seguinte: de acôrdo com as duas primeiras, terial havido no início da história do mundo uma Idade do Ouro, mas se Hesiodo quase nenhuma base deixava para que se pudesse afirmar a posibilidade do reinício do ciclo, jå a Sibilina admitiria o retôrno da Idade do Ouro, imediatamente após a Idade do Ferro; quanto às predições etruscas, encontrariam elas também o seu lugar nesta combinação, fazendo com que as 4 Idades de Hesiodo pudessem ser consideradas como um conjunto à parte, no curso dos 10 séculos da Sibila: (10).

De qualquer maneira, porém, o que se nota é que, pelo menos, de acôrdo com estas predições, não havia segurança quanto ao retôrno da Idade do Ouro no mundo pagão. A conclusões diversas seremos levados se considerarmos a! mesma questão entre os judeus, tomando como esteios duas fontes que já nos interessaram no capítulo anterior: os oráculos sibilinos e o livro de Daniel (11).

Vejamos então, inicialmente, a primeira passagem do profeta em que se trata do assunto, e que é o episódio do sonho de Nabucodonosor, interpretado por Daniel:

" $T u$, ó rei, estavas olhando, e eis uma grande imagem. Esta imagem, que era enorme, e cujo resplendor era excelente. tinha-se em pé deante de ti; e a sua vista era espantosa. Quanto a esta imagem, a sua cabeça era de ouro fino, o seu peito $e$ os seus braços de prata, o seu ventre e as suas coxas de cobre, as suas pernas de ferro, os seus pés em parte de ferro, em parte de barro. Estavas vendo até que uma pedra foi cortada sem auxilio de mãos, a qual feriu a imagem nos seus pés que eram de ferro e de barro, e os féz em pedaços. Então foi juntamente feito em pedaços o ferro, o barro, o cobre, a prata e o ouro, e se tornaram como a pragana das eiras de estio; e o vento levou-os, de sorte que não se achou lugar para êles. A pedra que feriu a imagem. tornou-se uma grande montanha que encheu a terra tôda."

"Este é o sonho; e diremos a sua interpretação na presença do rei. Tu, ó rei, és reị dos reis, ao qual o Deus do céo deu o reino, o poder, a fórça e a glória; $e$ onde quer que habitem os filhos dos homens, nas tuas mãos entregou os animais do campo $e$ as aves do céu, e te fêz reinar sôbre todos êles; tu és a cabeça de ouro. Depois de ti se levantará outro reino inferior a ti; $\mathbf{E}$ outro terceiro de cobre, o qual dominará sōbre a terra tôda. $\mathbf{O}$

(9). - Nogara, "Les etrusques". págs. 108-107.

(10). - Zielinski, "La Sibylle", pág. 107.

(11) - Apenas para esclarecimento, convem informar-se que o ponto de partida para a crença nas Idades parece ter sido babilonico-iránico. Cf. Bousset, "Die Reigion", pág. 504-50t; Autran, "La Prehistorie du Christianisme", U, DUE: 191 e ss.. 
quarto reino será forte como o ferro, porquanto o ferro faz cm pedaços e subjuga tódas as cousas; como o ferro esmiuça tôdas estas cousas, assim êle fará em pedaços e esmiuçará. Porque viste os pés e os dedos, em parte de barro de oleiro e em parte de ferro, será êle um reino dividido; mas nele haverá alguma cousa da firneza do írro, porquanto viste o ferro -misturado com o barro de lodo. Como os dedos dos pés eram em parte de ferro, e cm parte de barro, assim o reino será em parte firme e em parte frágil. Porque viste 0 ferro misturado $\operatorname{com} \mathrm{c}$ barro de lodo, misturar-se-ão com a semente de homens; porém nāo se apegarão um a outro, assim como o ferro não se une com o barro. Nos dias dêsses reis suscitará o Deus do céu um reino que jamais será destruido, nem passará a soberania dêste a outro povo; mas fará em pedaços e consumirá todos êstes reinos. e êle mesmo subsistirá para sempre. Porquanto viste que do monte foi cortada uma pedra sem auxilio de mãos, e que ela fêz em pedacos o ferro, o cobre, o barro, a prata e o ouro; o grande Deus féz saber ao rei o que há de acontecer no futuro. Certo é o sonho, e fiel a sua interpretação (12)".

Ora, não deixa de ser interessante que também aqui se encontre o mesmo pepel simbólico dos metais e, se bem que não haja expressamente mencionada à idéia de decadência, há sempre a degradação progressiva do metal simbólico, desđe o ouro até o ferro, e assim mesmo misturado com barro (13). Quanto à grande novidade dêste trecho, enccntrâmo-la na predição de uma verdadeira volta da Idade do Ouro (como a entendiam os pagãos), ou seja. ns' profecia do reino suscitado por Deus e que jamais seria destruido, porquanto consumiria todos os outros e subsistiria para sempre. E dizemos mesmo que se trata de volta, porque os judeus, sem que falassem com os mesmos têrmos dcs pagãos em "Idade do Ouro", colocavam no início da história do mundo um período paradisíaco, bruscamente interrompido pelo pecado original.

Três são es principais sistemas de interpretação do episódio da estátua (14): o romano, que é aceito por Santo Hipólito e São Jerônimo; o grego, de Santo Efraim Siro; e o siríacc, de autoria do filósofo neo-platônico Porfírio. O segundo e o terceiro sistemas terminam, pràticamente, por localizar no quarto reino os Diadocos, o que os caracteriza por serem orientados por um critério mais histórico-racionalista; o autcr do liviro de Daniel, escrevendo na época dos Macabeus, não teria vaticinédo a respeito de cousas futuras, mas simplesmente teria feito uma relação simbólica dos principais. impérios, desde o Labilônico até o de Antíoco Epifânio. E'os defenscres do sistema grego apoiam-se ainda no fato de que nada está contido no livro a respeito de um períado que ultrapasse a época de. Antioco IV.

(12). - Daniel, 2, 31-45.

(13). - "... parente evident avec le mythe des quatre ages du monde, 1.3ge d'o:, l'age d'argent, l'áge de bronte et l'age de fer, - tel gu'on le trouve sux inces, chez les Porses et chez tes Grecs, notamment chez Hésiode" (Lods, "Lu-Religion d'Israêl", pág. 220).

(14). - Inder, "Cormmentarius in librum Daniel", pag. 154 e se. 
O sistema romano, que é o que mais nos interessa, teria surgido como resultante da necessidade de uma reinterpretação dó livro de Daniel, que o adatasse às novas condições surgidas com a substituição do poderio grego pelo romano no Mediterrâneo Oriental (15); as diferentes partes da estátua corresponderiam, então, aos seguintes reincs: Neo-Babilônico, Medo-Persı, Greco-Macedônico (abrangendo o Império de Alexandre e o período dos Diadoccs) e Império Romano. Temos assim travado novamente contacto com o tema central do nosso trabalho: a idealização de Roma e de seu pepel na História.

No próprio livro de Daniel encontra-se outra narração de um sonho, desta vez do profeta, onde há novos símbolos que os intérpretes atribuem às mesmas idéias já expostas em relação ao sonho de Nabucodoncsor. Apenas, agora, os metais são substituidos por animais, como se vê:

"No primeiro ano de Belshazzar, rei de Babilônia. teve Daniel um sonho e visões da sua cabeça, estando na sua cama; então escreveu o sonho e relatou a soma das cousas. Falou Daniel e disse: Vi na minha visão noturna, e eis que os quatro ventos do céu irrompiam sôbre o grande mar. Quatro grandes animais, diferentes uns dos outros, subiam do mar. O primeiro era como um leão, e tinha azas de águia; enquanto eu olhava, foram-lhe arrancadas as azas, ele foi levantado da terra, e posto em dois pés como um homem, e foi-lhe dado um coração de ho-mem. Eis outro animal, o segundo, semelhante a um yrso, que se levantou sôbre um dos seus lados, e tinha três cớtelas na boca; e dizian-lhe assim: Levanta-te, devora muita carne. Depois disto estava eu olhando e eis outro, semelhante a um leoparco, que tinha nas costas quatro azas de ave; tinha o animal também quatro cabeças, e foi-lhe dado dominio. Depois disto vi nas visסes noturnas, e eis um quarto animal, terrivel e espantoso. e sobremaneira forte; tinha grandes dentes de ferro; devorava e fazia em pedaços, e pisava aos pés o que sobejava: era diferente de todos os animais que o precediam, e tinha dez chifres. Eu considerava os chifres, e eis que entre êles subia outro chifre. pequenino. deante do qual três dos primeiros chifres foram arrancados; e eis que neste chifre havia olhos como olhos de homem. \& uma boca que falava grandes cousas. Eu estava olhando até que foram postos uns tronos e um que era antigo de dias se assentou; o seu vestido era branco como a neve, e os cabelos da sua cabeça como pura lă; o seu trono era chamas de fogo, e as rodas do mesmo fogo ardente. De deante dêle manava e saia um rio de fogo; milhares de milhares o serviam, e miriades de miriades assistiam deante dêle; assentou-se o juizo, e abriram-se os livros. Eu estava olhando nesse tempo, por causa da voz das grandes. palavras que falava o chifre. Eu estava olhando até que foi morto o animal e destruido o seu corpo; e êle foi entre-

(15) - Charles, "Peligious development between the Old and the New Tesciments", pigs. 29 e 162-163: " $\ldots$ a now and more ruthiess power had taken the place of the Greek empire in the East. This new phenomenon called, therefire, for a fresis reinterpretation of Daniel. The fourth and iast empire, which. according to Dan. VII 19-25, was to be Greek, was now declared to be Roman by the ariter of 2 Baruch XXXVI-XI, and likewise by the avthor of 4 Eara X. $60-\mathrm{XII} .35$. 
.gue para ser queimado pelo fogo. Quanto aos outros animais, toilhes tirado o seu dominio; todavia as suas vidas foram prolongadas para uma estação e um tempo."

"Vi zas visōes noturnas, e eis que vinha com as nuvens do céu um como filho de homem, que se chegou até o antigo de dias; foi apresentado deante dêle. Foi-lhe dado domínio, e glória e um reino. para que todos os povos, nações e linguas o servissem; o seu dominio é um dominio sempiterno, que não passará, e o seu reino tal, que não será destruido."

"Quanto a mim, Daniel, o meu espirito foi contrariado no meio do meu corpo, e as visóes da minha cabeça me perturbaram. Clieguei-me a um dos circunstantes, e perguntei-lbe a verdade a respeito de tudo isto. Assim êle me disse, e fêz-me saber a interpretaçāo das cousas. Estes grandes animais, que são quatro reis, que se levantarão da terra. Mas os santos do Altissimo receberão o reino e possuirão o reino para sempre, sim, para todo - sempre. Então tive desêjo de sabèr a verdade a respeito do quarto animal, que era diferente de todes éles, sobremaneira terrivel. cujos dentes eram de ferro; e as suas unhas de cobre, que devorava, fazia em peçados e pisava aos pés o que sobejava: a respeito dos dez chifres que êle tinha na cabeça, e a respeito do outro chifre que subiu, e deante do qual cairam três, a saber, daquele chifre que tinha olhos, e uma boca que-falava grandes cousas, e pareceu ser mais robusto do que os seus' companheiros: Eu estava olhando, e o mesmo chifre fazia guerra contra os santos, e prevalecia contra êles, até que veio o antigo de dias, e o juizo foi dado aos santos do Altíssimo; e chegou o tempo em que os santos possuiram o reino."

"Ele disse assim: o quarto animal será o quarto reino na terra, o qual será diferente de todos os reinós e devorará tôda a terra, e a pisará aos pés e a fará em pedaços. Quanto aos dez chilres, déste reino se levantarāo dez reis; depois dêles se levantará outro; êle será diferente dos primeiros e abaterá a três reis. Ele falará palavras contra o Altissimo, e consumirá os santos do Altissimo; cuidará em mudar os tempos e a lei, e os santos the serão entregues nas mãos até um tempo e metade dum tempo. - Mas o juizo se assentará, e tirar-lhe-ão o dominio, para o consumir e destruir até o fim. O reino e o dominio, e a grandeza dos reinos debaixo de todo o céu, serão dados ao povo dos santos do Altissimo: êste reino é um reino_sempiterno, e todos os dominios o servirão e the obedecerão (16)".

Ora, a correspondência entre as imagens já era perfeitamente assente por Santo Hipólito (17), que teria composto o seu comen-

(16). - Daniel, 7, 1-27. Tal capttulo foi, por alguns, considerado como uma interpolaçăo cristã no Antigo Testamento. Cf. Christ. "Geschichte der griechiBchen Literatur". II, pág. 576: E. Hertlein "Der Daniel der Römerzeit", Leipzig. 1908, hat die vor $P$. de Lagarde, Gütt. Gel. Anz. 1891, 497-520, ausgesprochene Termutung, dass Teile des Danieibuchs aus der Römerzeit stanmen (Kap. 7 auq tom Jahr $68 \mathrm{n}$. Chr.\}, wieder aufgenommen und erweitert; auch $M$. Pflanzl, -Ein christiches Schriftstick in Alten Testament". Internat, Firchl. Zeitschr. ‥F.'A (1916) iti-209 deutet das 4. Danielische Reich auf Rom und erklërt Kup. 7 ais christliches Schriftstuck: vol auch $k$. J. Neumann, Lit. Zentralblatt f7 (1916) 811-813. In der Tat verschwinden bei dieser Annahme manche Schwierigkeiten der Erklärung: andererseits ist es, von anderem abgesehen, nicht wahrscheinlich dass ein so spiat abgeschlosstnes Buch noch Aufnahme in den altegtamentliche Fanon gefunden hätte".

(17). - "In Daniclen". I, III, in Migne, P. G., X: "I" - "Cum dixit imenem ex nseri, Babyloniorum regnum congtitutum significavit, et hoc esse sl- 
tário por volta de 202 (18). São Jerônimo, qưe certamente a êle recorreu (19), seguiu-o neste ponto, de tal modo que se torna bem clara a correspondência entre os símbolos, permitinda a elaboração de um pequeno quadro, abrangendo os capítulos 2, 32-45 e 7, 2-27 do livro de Daniel, tal como o fêz Aug. Bea (20):

\begin{tabular}{|c|c|}
\hline $\begin{array}{c}A \\
2,32-45: \text { Statua }\end{array}$ & $\begin{array}{c}\mathrm{B} \\
\text { 7. 2-27: bestiae }\end{array}$ \\
\hline 1) Caput: aurum $(2,37 \mathrm{~s})$ & 1) leo cum alis aquilae $(7,4)$ \\
\hline $\begin{array}{l}\text { 2) Pectus et brachia: } \\
\text { - argentum }(2,39)\end{array}$ & $\begin{array}{l}\text { 2) Ursus cum latere inaequali, } \\
3 \text { costae }(7,5) \text {. }\end{array}$ \\
\hline $\begin{array}{l}\text { 3) Venter et femora: } \\
\text { aes }(2,39)\end{array}$ & $\begin{array}{l}\text { 3) pardus cum } 4 \text { alis et } \\
4 \text { capitibus }(7,6) \text {. }\end{array}$ \\
\hline $\begin{array}{l}\text { 4) Tibiae et pedes; } \\
\text { ferrum et lutum } \\
(2,33.40-43)\end{array}$ & $\begin{array}{l}\text { 4) bestia terribilis cum } \\
10 \text { cornibus } \\
(7,7-8.11 .19-26)\end{array}$ \\
\hline
\end{tabular}

Quer-nos parecer - como já o dissemos - que a granđe importância destas passagens reside na previsão de umaı nova ordem, tal como se depreende de 2, 44-45 e de 7, 26-27. Mas o que se nota também, é que esta ordem só poderá ter lugar após o restabelecimento da justiça, violada pelo elemento simbolizado pelo $11 .^{\circ}$ chifre, mencicnado em 7,24 (21) e que pode ser interpretado de duas maneiras, conforme o sistema que se considere: se nos colocamos num ponto de vista estreitamente histórico-racionelista, tal ele-

mulacri caput aereum. Dicens autem alae ejus aqullae (significavit) regem Nabuciodonosor exajtatum, ijsiusque glorian contra Deum elatam fuisse. Deinde dixit evulsae sunt alae ipsius, quia eversa fuit gloria ejus; e regno enfm suo expulsus est. Dicens vero: Cor hominis datum est ei, et super pedes hominis stetit, (indicat) emm resipuisse, quando se hominem esse agnovit, ac dedt borian. Deo. Forro post leoenam, securdam bestiam vidit similem urso, qui erant Persae; namque post Babylonios, persae obtinuerunt. Dicendo autem, trlo latera in ore ejus, tres gentes ostendit, Persas, Medios, Babylonios; quemadmodum argenturi in simuiacro post aurum demonstratum est. Sequitur tertia bestia. nardus, qui erant Graecí namque post Persas Alexander Macedo, sublato Dario. rcrum poutus est; quod in simulacro aes indicavit. Quod autem dicit, alae quatuor volucris, et quatuor capita bestiae, luculenter ostendit quo pacto Alexandri dominatio in quotuor partes distracta fuerit; quatuor enim capita dicens, quatuor reges, qui ex ea surrexerunt signifjcavit: supremum enim diem objens Alezander, regnum suum in quatuor partes divisit. Postea. inquit, quarta bestia terribitis atque stuperda dentes ipsius ferrei, et ungues ipsius aerei. Quinam vero hi sunt, nisi Romani? Quorum regnum in praesentia exsistens ferro (in simulacro) comparatur; crura enim ejus, inquit, ferrea.

III - ... Caput aureum simulacri, est leoena, qua Babylonil repraesentabantur; humeri, et urachia argentes, ursue, quo Persae designabantur et Medi. ienter et feriors aenea, pardus, quo Graeci qui ab Alexandro imperarunt, significabantur; crura ferrea, bestia stupeuda, ac terribili6, Romani erant, qui modo Imperium tenent: ...

(18). - Bardenhewer, "Des heiligen Hippolytus von Rom Kommentar zum Buche Daniel", pág. 68.

(19). - Idem, pág. 10. São Jerônimo inclui Hípólito no "De Viris", 61.

(20). - "Quaestiones Iitterariae, criticae, historicae in 1. Daniels" (1937).

jp. 46 s. ap. Linder, op. cit., pág. 159.

(21). - Linder, op. cit. pág. 317 . 
mento será o próprio Antíoco Epífanes (22), e como "povo dos santos do Altissimo" o gutor teria em mente designai apenas Isreel, "para quem, nos desígnios de Deus o império do mundo está destinado (23)"; se considerarmos que o livro de Daniel trata de legítimas prcfecias, teremos então naquele símbolo o Anticristo tão falado e esperado pelos autores cristãos dos primeiros tempos de nossa era De qualquer modo, a conclusão será sempre a mesma: previsão de uma idade de Justiça após a punição de uma entidade maléfica e opressora; tal idéia servia de consôlo acs judeus, tanto mais quanto acreditavam êles ser evidente "que a duração do período de aflição fôra determinadaı desde o princípio, e que mesmo esta duração tinha um secreto significado (24)".

Quanto aos Oráculos Sibilinos judeus, encontramos também na sua parte mais antiga a mesma preocupəção de divisão da história do mundio em Idades, da sucessão dos impérios e da perspectiva de uma era messiânica, após o castigo dos opressores de Israel. Sem nos determos na complicadissima questão da locaìzação no tempo dos diversos trechos do livro III, uma vez que, com exceção de uns pcucos versos que alguns querem datar do primeiro século da era cristã, todo o amálgama deve ser situado entre 140 e 25 a. C. (25), pessemos a var as passagens mais interessentes de tais Oráculos.

Em um dos trechos mais antigos da composição - texto que já teria sido mencionado por Alexandre Polyhistor (mais ou menos em 80 a. C.) (26), - notamse a referência a uma décima Idade, marcada pelo reinado de Crono e que, portanto, deveria corresponder também à passada Idade do Ouro, cujo fím seria assinalado pela luta de Titã e de seus sessenta filhos contra: Crono (27). "Pa-

\footnotetext{
(22). - Lagrange. "Le Judaigme", pag. 66 .

(23). - Driver, "The book of Daniel", pág. 104: "The parallelism between the vision and the inetrpretation, is complece; the time is the same, the promige of perpetual and universal dominion is the same; and hence a strong preaumption arises that the subject is also the same, and that the "on like unto a son of man" in $\checkmark .12$ corresponds to, and represents, the "saints of the Most High" of v. 18, and the "people of the saints of the Most High" of v. 27, 1.e. the ideai Isrnei. for whom in the counsels of God the empire of the world is designed." (ap. Linder, op. cit., pág. 313, n. 1). Aliás, São Jeronimo é de opiniźo que os judeus sempre passarami a considerar a profecia em seu favor (Cf. Linder, op. cit., pas. 173).

(24). - Graetz, "A History of the Jewg", I, pág. 460.

(25). - Cr. Jearimaire, "Ld. Sibylle", pag. 5j n. 2.

(20). - Idem, pag. 101.

(27). - Vv. o7 e ss.: “... Mas, quando se realizarão al ameaças que o Granje Deus tinha proferjảo contra estes mortais que construiram uma tôrre no pais assfrio (éles falavam todos a mesma inngua e queriam escalar o céu estrelado...). Imediatamente o Imortal impos aos ventos uma grande lei fatal: \& imediatamente, os ventos derrubaram a tôrie, que era de uma altura imensa, e suscitaram querelas entre os mortais. Lis porque os mortais deram à cläade - nome de Babilonia".

"Quando a torre caju $c$ as linguas dos homens aiteraram-se em mil sons diversas, a terra inteira encheu-ge de mortais. e os reis partilharam-na. veio entāo a décima Idade dos homens com voz articulada, desde o catáchisma que cuira aobre os primeiros humanos. Então reinaram Crono, Titã e Japeto..." tAp. Delaunay, "Moines et Sibyneg dans l'antiquité judeo-grecque" pág. (336-297):
} 
rece, também, que o Eutor conta uma sucessão igualmente de 10 Idades, caracterizadas por outros tantos impérios e pela hegemonia dos diversos povos, desde o tempo de Saturno até a sua própria éprce, que, no seu pensamento - bミm entendido - ccrresponde a uma época crítica da história do mundo: nos versos 156-161 encontramos, com efeito, uma enumeração de 8 impérios sucedendose após o fim da era dcs Titãs (28)". Jeanmaire continua citando os versos mencionados (29) e anotando que "se trata, provàvelmente, como em Daniel, de impérios chミmados a exercer sucessivamente a hegemonia. $O$ ponto de vista é egípcio, o que explica a menção de um perícdo etíope (a XXVa. dinastia de Manetão)". Entre os versos 163 e 195 voltam os oráculos a tratar da sucessão dos impérios e, dando bem claræmente a idéia de seu caráter compósito (30), assim se expressam:

"O Deus Único me inspira afim de que eu possa revelar, em primeiro lugar tôdas as realezas humanas que surgirão."

"A primeira, a casa de Salomão, dominará a Fenicia, a Ásia, as Ilhas, as nações dos pânfilos, dos persas, dos frigios, dos cários, dos misios e dos lídios, que possuem ouro em abundância. Em seguida reinarão os gregos soberbos e cruéis; o povo da $\mathrm{Ma}$ cedônia reinará ao longé sôbre diversas regiones e suscitará aos mortais a temivel tempestade da guerra. Mas o Deus celeste tirárá as suas raizes até os seus fundamentos".

"Entãa virá o inicio de uma outra potência, branca e com muitas cabeças, vinda do mar do Ocidente. Ela reinará sôbre muitas regiōes, ela abalará muitos povos; ela espantará todos os reis; ela arrancará grande quantidade de ouro e de prata a um grande numero de cidades. Haverá novamente sôbre a terra divina o ouro e, depois, ainda o dinheiro e o luxo. Eles oprimirão os mortais. Estes homens cairāo depois de terem reinado com excesso de fasto e de iniqüidade. Neles residirá o gênio da impiedade; o macho se aproximará do macho; éles colocarão as crianças nos vergonhosos lugares do deboche. Haverá nestes dias uma grande tribulação entre os homens. Este povo desordenará tudo, quebrará tudo; devorado pela sêde execrável do ouro e por amor de um lucro sórdido, levará ao cúmulo as calamidades em muitas regiōes, sobretudo na Macedônia."

O que se vê de mais interessante para o nosso assunto, neste trecho, é já a mençãc expressa da pctência romana, que outra não é a "potência brancé e com muitas cabeças" (31) e que já é tra-

(2s) . - Jeanmaire. op. cit., páss. 102-103. Delaunaj, op. cit., pág. 254 e ss..

(29). - "E então Deus perdeu os Titãs; e tóda a descendéncia dos Titās e de Crono pereceu... Depois disto, no curso dos tempos, surgiu o reino do Egito; depois surgiram os dos persas, dos medas, dos etiopes, da Babilonia assiria, $\mathrm{cm}$ seguida o dos nacedonios, novamente o do Lgito, e depois o de Roma".

$(30)$. - Tal caratej evidencia-se porque é muito dificil que se posaa ver neste trecho a continuacäo do precedente, uma vez que, em caso coritrário, o sibilista ño só repetír-se-ia, mas ainda mais, cairia en contradicão. "Fstamos em pre. cenca de uma nova perspectiva nistórica, que nada tem a ver com a precedente" (Welaunay, oj. cit., pág. 334 , n. 4).

(31). - Delaunas, op. cit., págs. 256 e 341 , n. 1. Bousset, "sibyllen". pag. 270 . 
tada pelo sibilista judeu com ódio digno de nota, o que poderia ser interpretado como sendo, tanto o reflexo do sentimento do vencido amaldiçoanco o vencedor, como o eco de indignação do discípulo de Moisés, ao anatematizar os pigãos de costumes dissolutos (32). Os ataques a Roma, aliás, reptem-se em outras passagens do livio III como, por exemplo, no verso 520 e no verso 638, ao guvái já nos referimos.

Por fim a terceira grande idéia de que estemos tratando, a do retôrno de uma era de paz e de prosperidade, encontra-se támbém nos Oráculos, como se observa pela leitura das passagens seevintes:

"Mas logo a paz, reconduzindo a calma, virá sôbre a terra da Asta. Entáo haverá também felicidade para a Europa, época de fartura, de vida longa a de robustez, isenta de tempestade e de granizo, em que se multiplicarāo todos os animais da terra, os que voam e os que rastejam. Bem-aventurados os que viverão neste tempo, homens ou mulheres, como nos tempos fabulosos, sob o cajado dos Bem-aventurados. E que Boa Lei (Eunomia) dejxando o céu estrelado virá para ficar entre os homens, e Boa Justiça e, com ela, a Sábia Concórdia (Homonoia) preferivel para. os mortais a qualquer cousa, e Amor ao próximo, Boa Fé, Boa acolhida ao estrangeiro: ir-se-ão Má Lei, Má Ironia, Cólera, incompreensáo: Pobreza fugirá da Humanidade assim como a Fatalidade $e$ o Asasssinio, e as Discórdias mortais e as funestas Querelas (e os ladróes noturnos e todo o mal, nestes dias) (33)".

"A terra, que tudo produs, dará aos mortais excelentes fru. tos, frumento, vinho e azeite. Do céu correrá a doce beberagem do doce mel: as árvores prodigalizarão seus frutos; os gordos rebanhos de'bois, de ovelhas $\varepsilon$ de cabras multiplicar-se-ão ao infinito. Ele (Deus) fará brotar fontes agradáveis de leite branco como neve. As cidades regorgitarão de bens; os campos serão férteis. Não mais o gládio, não mais tumulto sôbre a terra; não mais éstes estremecimentos profundos que acodem o solo gemente; não mais a guerra, a séca, a fome, o granizo malfeitor e mortifero para os frutos. Uma grande paz reinafá sôbre a terra; - rei guardará amizade ao rei até o fim dos séculos; o Imortal no. céu estrelado dará aos homens por tôda a terra uma lei comum. que ensinará o que é necessário fazer aos mortais infortunados... (34).

“...E então surgírá um reino, que durará eternamente e que se estenderá sôbre tôda a humanidade. Aquêle que deu aos homens pios uma lei santa, prometeu a todos éles abrir-lhes a terra, - mundo. as portas dos bem-aventurados, tôdas as delicias, o espirite imortal e a felicidade eterna. De tōda a terra levar-se-á incenso e presentes à casa do Grande Deus; e não haverá outra casa a venerar para as geraçóes humanas do futuro sinão aquela que Deus deu ao respeito dos homens fièis. Os mortais a chamarão o Filho do Grande Deus".

"Todos os caminhos da planície, os rochedos escarpados, as altas montanhas, as ondas furiosas do mar, serão fáceis de serem

(32), - Deictunay, idem, idem.

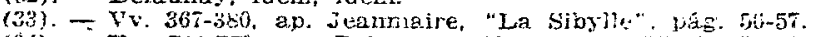

(34). - Fv, 744-755, ap. Irelaunay, "Mloines el sibjles" pág. 367-30. 
percorridas nestes dias. Una paz e uma felicidade profundas reinarão sôbre a terra. Os profetas do Grande Deus suprimirâo o gládio; porque êles serão os juizes e os reis equitativos dos mortais. Os homens gozarăo de riquezas que não serăo adquiridas por injustiça. Será a judicatura e a magistratura do Grande Deus."

"Alegra-te, ó jovem, estremece de alegria: Aquêle que criou - céu e a terra deu-te uma felicidade etema. Ele habitará em ti; a ti pertencerá a luz imortal. Os lobos misturados aos cordeiros comen a herva sôbre as montanhas; os leopardos e os cabritos pastarão juntos; os ursos vagabundos serão guardados juntaniente com as bezerras. O carniceiro leão comerá a palha da mangedoura como o boi: e ternas crianças os conduzirão encadeados. Ele (Deus) fará rastejar inofensivo sôbre o solo o arimal feroz. Os dragōes dormirão com as crianças sem preiudicêtlas: porque a näo de Deus estará sôbre êles (35)"

Mas, como sempre, êste quadro de felicidade complete só poderá ser realizado quando todos os povos cpressores dos israelitas (tão louvados $\mathrm{em}$ tantas passagens como "os homens que têm cuidado da justiça e da virtude) (36), sofrerem o merecido castigo, umai vez que "o julgamento de Deus cairá sôbre êles; todos perecerão sob a mão do Imortal (37)".

$E^{\prime}$ de se crêr que os textos acima invocadus nos dão perfejtamente, não só a idéia da situação de Roma como cabeça do último império, mas ainda mais, a de que ao domínio romano corresponderia o pior de todos os períodos e de que de suá destruição dependeria o retôrno de uma era de paz e de prosperidade. Tal era, que entre os pagãos recebia a designação de Idade de Ouro, seria consagrada entre cs judeus sob o nome de Período Messiânico, uma vez que as esperanças do Judaismo orientavam-se para uma era futura em que, zo contrário da presente - caracterizada pelo domínio das fôrças demoníacas e pelo afastamento de Deus do govêrno do mundo - o próprio Deus assumisse a direção dos' negócios tarrenos, enviasse o Messias, a fim dêste realizar o julgamento da humanidade, mandando os ímpios para os eternos pântanos do Inferno, destruindo os inimigos de Israel e, como novo Daví, mas muito mais poderosa, reinasse sôbre Israel engrandecido e sôbre todo o mundo (38).

Com o advento do Cristianismo tais idéias não sofreram, a princípio, modificações sensiveis, tanto assim que há tôda uma literatura que nos permite verificar a sua continuação durante $O$ início da nova época que se abria para o mundo mediterrâneo. Trata-

(35). - Vv. 767-795, ap. Delaunay, op. cit., págs. $368-370$.

(6). - Y. 234 , ap. Delaunay, op. cit., pág. 346. Aliás, trata-se de toda uma passagem dedicuda a louvar os israelitas, du qual o citado verso 6 apenas o primeiro.

(37). - V. (;72. aj. Delauray, op. cit. páz. 302

(38). - Folztmann, "Lehrbuch der neutestamentlichen Theologie". I. pags. 76 ss., 81, ap. Pfister, "Das Christentum und die Angst”, pág. 142; Cf. Guntermann, "Die Eschatologie des Hl. Paulus", pág. 3; Weber, "Tulturgeschichte als Kultursoziolorie", pág. 168 . 
se, em primeiro lugar, dos Oráculos Sibilinos, que continuam a surgir, mas com uma difєrença: agora, têm êles duas fontes, uma vez que, além de: judaica, há também a cristã (39). Tanto jưueus como cristãos mantêm as características essenciais desta complicada produção literária, repetindo-se, então, os protestos contra o dominio romano, as queixas dos judeus vencidos e dos cristãos oprimidos. e as esperanças no advento de ums nova era de felicidade, após o castigo da potência opressora; contrariando as páginas de glorificação aos destinos de Roma, e que são tão marcantes na literctura do período, o que se reflete nos Oráculos é o ódio aos romanos, a cóiera e o desêjo de vingança e de desforra do Judaismo ou do Judeu-Cristianismo. E' o que leva Boissier a afirmar que "devemes render justiça zos poetas sibilinos, que não variaram nos seus sentimentos. Antes mesmo de ter scfrido o jugo dos romanos, já êles detestévam Roma. Seu poder não era ainda senão uma ameaça longínqua, suas legiōes não haviam ainda aparecido no Egito e na Síria, e êles a assinalıvam a todo o mundo como um grende perigo e uma grande inimiga. Naturalmente, detestaramna ainda mais quando a ecnheceram de perto. Uma vez conquistado o murido, as imprecações redobraram. Tcdos êstes pcetas, freqüentemente de opiniões diversas e que pertenciam a religiōes diferentes. entraram em acôrdo no ódio que sentiam em relação a Roma, na alegria que experimentavam co anunciar-lhe a punição próxima e ao descrever de antemão o seu castigo (40)". S S continuarmos a observar $c$ conteúdo dos oráculos, teremos bem depres$s \_i$ a oportunidade de verificar o acerto destas palavras. Vejamos assim, primsiramente, os sibilinos judeus posteriores ao advento do Cristianismo e dos quais os mais interessantes para nós são o quarto e o quinto.

O livro IV é particularmente notável por ter sidc escrito sob a influência dos desastroses acontecimentos que culminaram com E tomada de Jerusalém por Tito, em 70, e com a distruição do templo, a que não pode ter deixado de contribuir para que mais densa fôsse a ira do sibilista (41). Como já se viu no livro III e como se verá também entre cs cristãos, surge no livro IV a divisão da história do mundo em 10 idades, correspondendo sempre o domínio romano ao fim da $10 . a$ idade (42), desempenh:ndo Roma o papel de grande inimiga do povo eleito: ncs versos 115-116 é feita referência à guerra de Pompeu no Oriente e à tomada do templo

(39). - A primeira obra cristã $\mathrm{em}$ que a Sibila aparece \& o "Pastor" de Hermas, na visão II. \& 4 . Cf. Lanchester. art. Sibvlline Oracles, in "Encvolonedia of Relizion and Ethics" : Wendland. "H. R. K.". pág. 387: Primm,

"Seltsame Heilandsnropheten", pág. 610.

- (40). - Boissier, "La fin du Paganisme", II, páf. 22.

(41). - Ci. Geffcken, "Neutestamentliche Apokryphen", pá. 401.

(42). - T. 38 ss.: T te (Deus) que... me ordena que anuncie exatamente ans homens o que aconteceu ate agora, o que acontecerú maís tarde, desde a primeira idade até a decima". Idem, .v. 48 ss.: "Agora direj o que acontecerá. a. partir da prineira idade" (segue-se a descricăo das fandes). 
(43), acompanhada por "assassínios abomináveis" e, logo em seguida, à própria campanha de Tito, como se vê:

"Um chefe romano virá para a Síria $e$, após ter entregue o templo às chamas, passará a fio de espada muites habitantes de Solima e arruinará a grande e magnifica região dos judeus (44)":.

O castigo não tardaria a cair, entretanto, sôbre a cidade peadora, e sibilista vê o seu primeiro indício na erupção do Vesúvio (45), sinal de que a ira divina já se abatia sôbre os que exterminaram a raça inocente dos homens piedosos (46); seguir-se-ia uma série de catástrofes, depois das quais Roma restituiria em dôbro tôd:s as riquezas que tivesse roubado à Ásia (47). Após êste prelúdio sobreviria então o castigo final, em virtude do qual os homens, as cidades, cs rios e o mar seriam destruidos, sendo o mundo transformado numa poeira denegrida (48); e depois disto instalar-se-ia o julgamento divino, findo o qual aquêles que tivessem praticsdo a piedade reviveriam "no mundo imperecivel e bemaventurado do Grande Deus Imortal", que como recompensa de sua piedade dar-lhe-ia a "respiração, a vida e a alegria" (49). Este quadro de felicidade motiva então as $p=1$ lavras finais do poeta: "Oh! feliz o homem que viver até tais tempos" (50).

O livro IV é uma das últimas coleções de oráculos surgidas antes do aparecimento de seus congêneres cristãos, remontando aproximadamente ao ano 80 (51), e não deixa de ser interessante notarmos que não há unanimidade entre os comentaristas a respeito de sua origem exclusivamente judia; de fato, um dos mais considerados entre os conhecedores do assunto, Ch. Alexandre (52),

(43). - "A runesta tempestade da guerra cairá também da Itália sobre Solima, e devastará o grande templo de Deus. Quando, confiando na sua loucura e uitrajando a piedade, tiverem êles cometiỏo assassinios abomináveis ao redor do templo..."

(44). - IV. 125-127.

(45). - IV', 130 ss.: "E quando das entranhas rasgadas da terra da Itália uma chama lançar-se até o vasto cêu, consumindo muitas cidades, fazendo perecer os homens e enchendo com uma cinza obscura a imensidão dos ares: quando gotas aemelhantes ao vermelhūo cairem do céu, reconhecer-se-á então a ira do Deus Celeste, ira causada pela perda da naço inocente dos homens piedo8os." Cf. Jeanmaire, "La Sibylle", pág. 54.

(4i). - Cf. Simon,. "Verus Israel". pág. 63.

(47). - IV, 145-147.

(4S). - T , 152 e ss..

(49). - TV, 178 e ss..

(50). - IV, 190. Cf. III, 3t1.

(51). - Bousset, "Sibyllen". pág. 276 ; Simon, "Verus Israel", pág. 57; Delaunav, op. cit., pág. 323; Christ, op. cit., II, pág. 614; Puech, op. cit., II, 607. (52). - Ap. Delaunay, op. cit., pr. 375, n. 1, não aceito pelo autor, gue ve em certos traros do livro IV, como por exemplo, a atenuação do papel Aominaror e gifrioso de Tsrael, a expreasão da larkueza de vistas do monaquismo judeu-alexandrino (op. cit., pá. 3sf, n. 1). Simon, afirmando o carater integralmente sudeu do lirro IV, atribui tais tracos a uma conceprio espiritualista fus o poeta deveria ter a respeito do culto ("Verus Iarael". pág. 57, 59). Näo percamos de vista, entretanto, que "Jes juifs de la diaspora re se séparaient vas, au noint de vue religieux. de Jérusalem, leur métrovole; tout au plus marquaient-ils une inciination plus nette vers un culte spirituel et vers un universalisme thforioue et pratique plus franc" (Bonsirven, "IS Judassme Palestinien au temps de Jésus-Christ". I, p\&g. VI). 
opina pela crença cristã do sibilista, o que contribuiria para que se pudesse-afirmar a semelhança de sentimentos entre judeus e cristãos em relação a Roma, no primeiro século de Cristianismo. De qualquer maneira, porém - e juntamente com o livro $\mathrm{V}$ - está o livro IV numa situação de marco na cronologia dos oráculos sibilinos, porquanto al partir da época de sua composição principiam a surgir também os oráculos indiscutivelmente cristãos, ou judeu-cristäos, ao lado dos judeus e calcados nestes (53).

No livro $\mathrm{V}$, em que apenas algumas interpolações cristãs impedem que se fale numa coleção exclusivamente juđia (54), repetem-se os temas da profecia da era messiânica e das ameaças contra Babel-Roma, em declarações apaixonadas que revelam o ódio exasperado de sua origem judáica (55). Mais violentas do que as do livro IV são as imprecações contra Roma, duplamente culpada, como impia e pecadcra e como perseguidora dos judeus, "cidade má, detestável entre tôdas... essencialmente impura... de coraçáo criminoso e ímpio (56)", causa da morte de muitos enધre os hebreus, "santos e piedosos (57)", que acabará terrivelmente castigada pela ira divina, precipitada nas chamas ardentes do Tártaro, morada infernal dos criminosos (58)", enquanto que as provaçōes serão poupadas à "raça divina e celeste dos judeus bem-aventurados"; mesmo porque as catástrofes não atingirão a Palestina, sede da glória futura dos judeus (59).

(53). - Bousset, "Sibyllen", pág. 269. Lücken, "Die sibyllinischen Weisssúgungen". pág. 35, pretere a designação judeu-cristâos, em lugar de cristãos, para tais oráculos.

(54). - Trata-se dos versos 256-259. Cf. Geffcken, "Handbuch zu den Neutestamentlichen Apokryphen"; Christ, op. cit.. II, 614, n. 9; Puech, op. cit., II, 607. n. 2. $\in m$ que o autor é de opinião que também os versos situados nas imediaçōes do de numero 18 são interpolados cristāos.

(55). - Blass, in Kautzscin, op. cit., pág. 183. Tal énfase explicar-se-ia em irtude das circunstancias em que, provavelmente, loj composto o livro v, na cpoca da destruição do templo (Geffcken, ap. Bousset, "Sibyllen". pág. 276): não são desta época, entretanto, os versos iniciais, de 1 a 51 , originados no perfodo đos Antoninos. Quanto a autoria. há divergências: Geffcien. "Komposition und Fntstehungszeft der Oracula Sibyllina", pág. 238, ap. Christ. op. cit., II, pág. 614, a. 12) opina por um único autor para a principal parte do livro, que se estende do v. 53 a 511: Schurer ("Geschichte des judischen Volkes im Zeitalter Jesu-Christ", III pág. 581 ss., ap. Christ. op. loc. cit.) e Zahn ("Zeitschrift f. kirch. Wiss. u. Leben", Vh, 37 ss, ap. Bousset, "Sibjllen", pág. 276), ao con"ririo, prelendem distinguir aí vários autores.

(50). -. Vv. 165 e ss. Cf. Sirnor, up. cit., pág. 63.

(57). - Vv. 160-161. Cf. Simon, idem, idem.

(50). - Vv. 172-178: "Tu nâo reconheceste do que Deus é capaz e o que Du pode chegar a fazer, mas tu dizias: eu sou a únici, e ninguém me destruirá. Mas agora o eterno Deus destruirá a ti e a todos os teus, e nāo mais existirá de ti. sinal algun naquela torra, comc antisumente, quando o grande Deus descouriu a tua glória. Fíca só, infúme, e com o fogo fímejante misturando-se a ti, toina cumo murada, no Hades, o tartárico, abominável lugar."

(59). - Vv. 248-250: "... assim será naquejes dias a divina raça dos bemaventuradas.judeus de origem celeste, que habitam nos arredores da cidade de Deus, no interiot áas terris...".

V.: 260-268: "Não mais atormenta o teu coração "no peito pela espada", tu ie origeni divina, tu, Hica, única flor almejada, nobre luz e digna vergontea, anado rebento, suave, bela cluade judia, por Deus inspirada para as cancōes. Não mais bacanalmente delirara ao teu redor na tua terra o impio pé dos Helenus, alimentando sentimentos criminosos no peito, mas teus filhos valorosos honcar-te-ão até as alturas e aproximar-se-āo com cançōes, com suntas línguas, hinrando g. Déus com sacrificios e votos de thida a espécie". Cf. Simon, op. cit., pág. 65. 
Os cristãos, ou melhor, judeu-cristãos, fizeram modestas imitações dos oráculos de origem exclusivamente judia $e$, segundo a opinião de Bousset (60), apenas compuseram obra de importância secundária neste ramo; além disto, tal produção foi tendendo a desaparecer, à medida: que decaia o judeu-cristianismo. Nos oráculos atribuidos aos cristãos (61) verifica-se, à primeira vista, a repetição dos temas já tratados pelos sibilinos judeus, tal como sejam, por exemplo, o da divisão da história do mundo em 10 idades (62) e o das imprecações contrai Roma, cujo domínio precederia imediatamente a grande catástrofe desencadeada por Deus e em seguida à qual se instalaria o Juízo Final (63). Mas, de todos êstes oráculos, o mais interessante pera nós é o VIII, que se destaca mesmo como legítimo e completo exemplo da sibilística, nele representada em todos os seus aspectos: ódio contra Roma, um trecho da história dos imperadores, lenda de Nerc, escatologia, his. tória sacra.

Interessa-nos mais, entretanto, $O^{\prime}$ ódio do sibilista contra Roma, o que dá idéia de uma atmosfera de conflito, refletida nas violentas imprecaçōes anti-romanas; bastante significativo é o fato de que Roma não mais é designada pcr expressões simbólicas, mas pelo seu próprio nome, como se pode observar em diversas passagens (64).

(60). - "Sibyllen". pág. 269.

(61). - Segundo Gefcken. "Handbuch zu den Neutestamentischen Apocryphen", seriam os seguintes: 1, 319-400; II, 34-153; 238-347; III, 1-45; 63-98; 37: i76; $\mathrm{V}, 256-259$; VI; VII; VII1; XII, 28-34; XIII, 87 8s. ; 100-102.

(62). - II, 15; VII, 97; VIII, 199.

(63). - Mesmo em relação dos versos 71-93 do llvro III poderemos ter um exempio. se aceitarmos a hipótese de Geffeken de que a viúva a que se referem Estes versos interpolados seja a própria Roma "Handbuch...", pág. 343. Cf., contra, Jeanmaire, "La Sibylle" pág. 123).

(64). - VII1, 37-45: “Um diá virá a ti do aito, arrogante Roma, o merecido golpe celeste, e primeiramente tu inclinarás a nuca e serás extirpada do solo, e o fogo devorar-te-á completamente, a ti, extendida sôbre o teu chão, e a cjuléncia será destruida, e lobos e raposas habitarão o local dos teus alicerces. Fi então estará tu completamente só, como se nunca houvesses exístido. Onđe está então o Paládio? Que Deus salvar-te-ḱ, seja êle de ouro, de prata ou de bronze? Uu onde estão então as decisôes do teu Senado ?"

VIII, 73-77: "E então" entristecer-te-4s, depois de teres despido as vestes de seneral em chefe com largas iaixas de púpura e que tenhas posto o traje de iuto, tu, fanfarroníssima rainha, filha da terra latina, Roma. Não mals falarás i: tua soberba, nāo mais levantar-te-ás tu na tua infelicidade, mas permanecerás lor terra"

VIIT, j3-104: "Mas prinielranente cairá sobre os romanos a ira inexorável, vira um tempo sedento de sangue e una vida funesta. Aí de ti, terra italica. wovo sumamente bárbaro! Nunca considerastes de onde viestes, nu e desprezado nera luz do Sol, por isto deves ir nu para o mesmo lugar e mais tarde deves vir para julgamento, porqúe tu julgaste injustamente........ Só em todo o riundo, por meio de gigantescás mâs, virás das alturas para baixo, e habitarós então sob a terra. Com nafta e asfalto e enxofre e nuita togo serás destruida e transformar-te-ás num pó queimando pela Eternidade: ..."

VIII, 120̄-130: "I não más serão colocadas sob o jugo dos escravos as nucas dos sírios, dus grejos, dos bárbaros ou de qualquer outro povo. Seras comlietamente destrufda, e de ti será novamente cobrado o que tu exigiste, e solucando darás os tributos, até que tudo tenhas pago; e serás um triunfo para o mundo e de todos serás objeto de insultos".

Noutra paesagem es inencionado o Tibre, o que resulta na mesma cousa: 
Como já fizemos notar ao tratarmes de outras passagens dós oráculos, o castigo e a destruição de Roma, previstos pará o ano 194, conforme de depreende do verso 148 (65), serão o sinal para o firn do mundo e para a realização do Juízo $\mathrm{Final}$, anunciaco por uma série de fenômenos cósmiccs tão do gôsto desta espécie de literatura: Outras idéias próprias aos livros sibilinos judeus encontram-se também aqui, come, por exemplo, a divisão $\mathrm{d} \equiv$ história do mando em idades (66), a violenta censura à cupidez romana (67) e a profecia que já se encontra antes nos livros III, 350-355 e IV, $145-148$, de que Roma restituirá à Ásiz tôda's as riquezas que the tivesse roubado (68). $T_{a l}$ repetição parece-nos poder ser invocada para que se afirme que o livro VIII, ainda que escrito por um cristão, o foi por um cristão estreitamente ligado ao Judaísmo, pcr um judeu-cristão, tanto assim que há lugar parミ passagens como esta, referente a Adriano:

"Mas quando a ti, luxuiosa, tịverem sido dados três vêzes cinco imperadores. os quais tenham subjugado o Orbe terrestre desde o levante até o poente, então haverá um soberano de cabeça branca, com o nome de um mar (Adriano!), que visitará o mundo com pés impudicos, obterá presentes para si e que, apesar de ter em abundáncia ouro e prata, acumulará ainda mais os dos inimigos, rouba-los-á, a depois voltará (para Roma) (69)".

Ora, ao que se saỉba, Adriano não adotou em relação aos cristâos uma política que lhe valesse tais vitupérios, mas, em compensação, foi muito mal visto pelos israelitas, em virtude do que fêz na própria Judéia e das medidas que tomou para com os judeus. De fato, considerando que fôra completamente extinta a grande revolta que, iniciada sob o govêrno de Trajanc, só por êle próprio fôra encerrada (70), Adriano "acreditara que os judeus esivessem definitivamente combalidos, não mais tendo lembrança do antigo papel de Jerusalem (71)"; resolvera, então, edificar no seu local uma nova cidzde, colonia de veteranos, que deveria rece-

VII:, 32-64: "E então, jrevendo o teu funestissino destino, lamentarão em -onum. pais e fihos menores. Gemendo lamentarāo eles tristemente, junto aos turbilh jes do Tibre".

(In Hennecie, "Nieutestamentliche Apokryphen").

(as). - "Mas trés rézes trezentos anos e mais quarenta e oito completarás tu. .." (in Henneche, op. cit.).

(fii). - VIJj, 6 \& ss.

(6) - VIII, 17 e $8 \mathrm{se}$.

(GS), - VII, T2.

(69). - VII, 00-50. Tal passagem serve de base para que Puech opine em favor de uma autoria completamente iudia para o divo VIII, 1-216: "Je ne vois, pour ma part, aucune raison bjen solide de considerer comme chrétiens les co's 1-216. L auteur de cette Apocalypse aésigne clairement Hadrien au vers 52 : if lu predit au moins trois sucesseurs au vers 65 ; il attend la ruine prochaine de . Home, qu'il deteste, et se réjouit en Eroquant "la chute des légions porteuses "ajkles it. Ts;"; c'est sans doute un Juif. qui écrit à la fin du II.e siecle". "Histoin: de la litterature Grecque Chretienne". II, pag. 010)

(70). - CR. Juster, "Les Juifs dan l'Empire Romain”, II, pág. I8J ss.; Iriccioti, "Histoire d'Terael", Ir, pkg. 570 ss..

(i1). - Chapot, "Le monde Romain". p\&g. 250; Mommaen, "Das Wittreich der cresaren", pág. 39ó. 
ber o nome de Aelia Capitolina (72). Um santuário a Júpiter Capitolino seria também erigido no local, e passaria a receber o didrachma em lugar de Jeová. Além disto Adriano incorrera na ira judáica por uma outra medida, particularmente grave: assimilando a circuncisão à castração, determinara êle que lhe fôssem eplicadas as penas cominadas na lei Cornélia de sicariis et venificis, que se caracterisava pela sua severidede (73). A interdição da circuncisão não tinha ccmo objetivo atingir apenas aos judeus, uma vez que árabes e samaritanos também foram incluidos na decisão imperic1; mas, para os judeus, a questão tomava aspectos muito maiores que para os outros atingidos pelo decreto, não só porque a propaganda do Judaísmo seria grandemente afetada (74), mas também em virtude do estado de exaltação febril em que se achavam os israelitas desde a catástrcfe de 70 e que os levava a esperar permanentemente os sinais prenunciadores da vinda do Messias e do triunfo final sôbre al potência opressora (75). Havia, assim, motivo de sobra para que os judeus, ou cristãos ainda a êles ligados, atacassem a pessoa do imperador, tão bem identificado, não só pelo verso 52 , mas também pelos de números 56,57 e 58 .

Outra passegem em que se revela a ligação do autor com o elemento judeu é a dos versos 140-141 em que, apesar das lacunas dcs versos 139 e 140, lê-se que, em dádo momento, o povo hebreu surgirá para consumir os pagãos e castigar Roma, como está expresso nos verscs 142 e ss. (76).

Como era de se esperar, o livro VIII encontrcu repercussäo bastante má em Rome; que não podia tolerar êste "ocultismo revolucionário", como o designa Geffcken (77), tanto assim que foi

(72). - Esta teria sido a causa da revolta, segundo Dião Céssio, 69. 12. $\boldsymbol{1}_{\text {, }}$ ap. Juster, op. cit., Il, pág. 191. n. 2. Esta cidade foi, na realidade, edificada, e 0 none de Jciusalem perdeu-se completamente no mundo oficial, a tal ponto fue, no século IV, o governador da Palestina, a quem um cristão falava de Jerusalem, nem nesmo sabia o seu sítio. Cf. Juster, op. cit., II, pág. 193, n. 3.

(73). - Juster, op. cit., I, pág. 265).

(74). - Guignebert, "Le monde Juif vers le temps de Jesus", pág."305. Segundo Esparciano, "Hadrianus", 14, êste édito teria sido a verdadeira causa. to levante de Bar Focheba. Quanto à data do decreto, achamos conveniente transcrever a nota de Juster a respeito, após citar a trase de Isparciano: "moverunt ea tompestate et lidaei beilum, quod vetabantur mutilare genitalia". $x_{a}$ date će cel édit varicra selon qu'on admet qu'il provoqua la guerra - et c'est cc que le texte dit - ou qu'il tut une consequence de la guerre - opinion zoutenue par plusieurs savants. Pour la prémière opinion, entre autres. 0 . T Sehoiz, "Jas Leben des Kaisers Haurian", p. $\$ 3$, 1904 L., qui est trop précis en mettant l'an 130 comme jate de l'édit. En 'effet, s'il est vrai que la guerre n'a pas Eclaté immédiatement après l'edit, et le texte de Dion laisse entendre que les Juils ont temporisé, il n'est guere certain qu'ils aient attenau un an" (op. eit., II, pág. 1j1, nota 1.;.

(75). - Hicciotti, op. cit., Ir, jág: 574-575. Havia ainda o rato bagtante significativo de que tal medida contra a circuncisão assimilava Adriano a Antóco $\mathrm{lV}$. que adotara decisão idêntica (I Mac. 1,43 sa.; cf. 1, 53 e II Mac. 6, 111; Jos. Ant. i2. 5. 4., ap. Juster, op. cit., I, pág. 264, nota 1).

(76). - VIII, 140-144: “...virá, para arruinar a raça dos pagăog e inümeros truncos, o povo houreu. Entũo Áres sugará até a última gota, ele proprio destrutrá a ameaça exorbitante dos romanos. Estará então liquidado o İoresrente dorifnio dos romanos assinn como a velba dominadora sóbre muitos viź nios." (In Hennecke, op. cit.).

(77). - In Hennecke, op. cit., pas. 401. 
estabelecida a pena de morte para a leitura de escritos desta ordem (78).

Pelo que se viu, pensamos ter ficado claro o parentesco judeu-cristão em relação dos oráculos. Um outro testemunho do mesmo fato, e êste muito meis famosa, é constituido pela literatura apocalíptica, iniciada em Israel graças às transformações introduzidas pelo livro de Ezequiel no velho estilo profético e cujas regras foram definitivamente fixadas pelo livro de Daniel (79). Os apocalipses são do mais alto interêsse para nós, em primeiro lugar, por serem considerados hoje em dia como um genuíno produto da inspiração judaica $(80)$, e em segundo, por surgirem sempre em épocas de catástrofe nacional, com o objetivo de reconfortar os judeus, mostrando-lhes que sua infelicidade nada mais era do que o sinal evidente do reerguimento próximo (81); e como não foram poucas as vêzes em que os judeus tiveram que enfrentar a adversidade, êste fato teria tido como resultado a aquisição, por parte dos israelitas, de uma verdadeira "mentalidade apocalíptica (82)".

O mais antigo apocalipse, depois do de Daniel, foi o de Enoch, cujas partes foram compostas em épocas diferentes, por autores diferentes, de tal modo que seus elementos mais antigos remontam mesmo ao perícdo pré-macabezno e os mais recentes aos ancs $95-64$ a. C. (83). Não nos deteremos sôbre tal livro por não haver nele gránde interêsse para 0 nosso assunto (84), bastando que se diga que são aí repetidas várias das idéias que já encontramcs antes: impérios simboiizados por animais, os sofrimentos de Israel sob um jugo injusto, a desforra e a vitória dos judeus sôbre os seus injmigos que perecem exterminados, o juízo divino seguido pela punição dos maus, destruição da terra e creação de um novo mundo, teatro da felicidade completa (85). Noutras palavras, como já tivemos oportunidade de dizer acima: a idade do Ouro, $m=s$ do ponto de vista de Israel, isto é, no futuro, depois da desforra dos judeus sôbre os opressores, todos êles de antemão condenados (86).

Como é evidente, os cristãos receberam dos judeus a literatura apocalíptica, e já os trechos escatológicos que se encontram

(78). - Justino, Apol. 1, 44, apud Geffeken, op loc. cit..

(79). - Renan, "O Antj-Christo", pág. 246.

(80). - Charles, "Religious development between the old and the nex Testaments", pa.g. 18; Mac Neile, " $\mathrm{An}$ introduction to the study of the New Testament", pap. 235 .

(8i). - Guignebert. "Le monảe Juif vers le tempg de Jesus", pág. 32.

(82). - Guignebert, op. lic. cit.: Renan, op. cit., pág. 247.

(83). - Charles; op. cit., pag. 224. Para Charles "Pseudoepigraphn", págs. 170-171. ap. Feran, "Cambridge Ancient History". VII, pág. 512), certas partes aeste fivio serium mais antigas do que o de Ijaniel.

(81). - "Die Bilderreden des I. Henoch. ... richteten sich noch nich gegen aie Weithersachaft Roms als sulche, sondern gegen die den Erdball in Verwirrung setzenden roemischen Gewalthaber" (Bousset. "Die Religion", púg. 218).

(85). - Cf. Delaunay, "Moines et Sibylles". pógs. 220 sE.

i. (86): - XXXVIII. 3; XLVIII, 8. Cr. Lagrange, "Le Judaisme", pag. 89; Rousget, "Dir Religion", pag. 243 e 207. 
no Evangelho de Marcos e na segunda epístola aos tessalônicos repousariam em antecedentes judaicos (87); ora, o Cristianismo teve que suportar também a hostilidade romana, e nada de admirar que accntecesse então $\mathrm{ccm}$ a apocalíptica o mesmo que sucedeu com a sibilística: ligados inicialmente aos judeus, sofrendo perseguições da mesma potência que continuamente humilhava Israel, os cristãos tiveram tôd: $\mathrm{s}$ as condiçôes favoráveis para o lançamento de um famoso apccalipse, que foi atribuidor a São João; nessa obra, "tôda a soma do fanatismo apaixonado acumulado pelo Judaísmo durente os períodos de opressão e que durarte as últimas décadas anteriores à destruição de Jerusalem fôra levado ao máximo da exaltação, liga-se, por intermédio do autor judeu-cristão, às impressões do presente (88)", originando um ardente manifesto antircmano, em que "retorna à cêna todo o material trødicicnal, visões de profetas israelitas, rudimentos míticos e fragmentos de história antiga, tudo refundido à maneira cristã (89)". O resultado disto foi - aparacimento, na literatura grega cristã, de uma obra complicada, enigmática (90), que desde cs primeiros séculos de nossa era já merecia as designações de ininteligivel e de inca:rente (91).

Pondo de parte as inúmeras discussões e dúvidas que até hoje têm sido suscitadas pælo Apocalipse do Novo Test:mento, vemos que nele apenas interessa ao nosso assunto uma questão: a referente às profecias e invectivas anti-rcmanas oriundas de uma mentalidade judeu-cristā, nər qual prepondera o elemento judeu. Para que possamos examiná-la deveremos tratar do Apocalipse sob. três aspectos: o primeiro, concernente à éxistência de um sentimento anti-romano, o segundo, referente à época da compcsição do livro e o último, atinente à sua autoria.

1 - O estudo das profeciss do Apocalipse deu lugar a uma série de comentários e interpretações diversas, mas tôdas elas podem ser agrupadas em 3 clisses: a primeira abrange os intérpretes para os quais o livrio em questão contém predições relativas a tôda a história da Igreja; na segunda estão os autores que são de opinião que o profeta tratou apenas dos primeircs tempos do Cristianismo; a terceira reune aquêles que restringem o âmbito das visões apenas aos últimos tempos da Igreja (92). A maior parte dos hermeneutas, entretanto, está incluida ná segunda classe, procurando

(\$7). - Wendland, "H. R. K."' pag. 381.

(\$S). - Idem, pág. 252.

(89). - Ideri, pág. 352 .

(90). - Cf. Melieile, "An Introduction to the study of the New Testament", pág. 239: "The book has at all times proved an enigma, and many writers finding thernselves unable to arrive at any satisfactory interyretation, have contented themselves with studying its language philologicaliy".

(91) - E o caso le Dionisio de Alexandria, que viveu no seculo III, Cf FusGbic. "Historia Lcclesiastica", i, 25. 1, ap. Guignebert, "Le Christ", pá. 31. (92). - Carluy, art. "A pocalypse" in "Dictionnaire de la Bible" publicado soh a direção de Vigouroux.

E certo que há sistemas que escapam a esta classificação, assim como o de van den Bergh van Eysinga, ap. Ruzer, op. cit., IIr, pág. 1t, que é o único entre os autores consultadus que o nenciona. 
sempre a interpretação das principais passagens nos acontecimentos da época (93). Os iniciadcres desta corrente foram Salmeron, Alcazar e Foreiro, e entre cs seus mais famosos adeptos encontrase Bossuet, com sua obra "L'Apocslypse avec une explication". Conforme nota Carluy, tal classe de interpretes "nada sabe nos dizer de preciso quanto aos cráculos dos últimos capítulos do Apocalipse, mas parece que não se pode negar que explicam de maneira muito plausivel a maior parte das predições que, segundo êles, dizem respeito aos quatro primeiros séculos da história da Igreja. E' verdade que há discrepâncias relativas à explicação de certos detalhes des visões; mas há acôrdo quanto à substância, e divergência quants aos detalhes (94)".

Assim seado, e procurando-se o ponto essenci 1 em que tais exegetas são unânimes, encontrá-lo-emcs no ódio ao culto imperiaí e zo próprio Império Romano, ódio êste pintado em côres particularmente ardentes e expressivas. A cidade de Roma, mencionada freqüentemente scb o ncme de Babilônia, como se vê também na saudação final da primeira epístola de S. Pedro (95), é objeto das mais violentas invectivas, sendo preditcs o seu castigo e a sua queda em têrmos bastante eloqüentes, como se poderá verificar:

XIV, 8: "E outro anjo seguiu dizendo: E caida, é caida Babilónia, aquela grande cidade, porque a tôdas as naçóes deu a beber do vinho da ira da sua fornicação."

XVI, 19: “...; e a grande Babilônia veio em memória diante de Deus. para Êle the dar o cálix do vinho da indignaçăo da sua. ira."

Os capítulos XVII e XVIII são integralmente destinedos a Babilónia (Rcma) e à sua queda; a cidade surge também sob a forma de uma mulher, em cuja testa se acha a inscrição "Mistério, a grande Bミbilônia, a mãi das prostitutas e das abominações da terra", montada sôbre uma besta de szte cabeças, cabeças estas que logo adiante são explicadas como tendo um duplo sentido: significam tanto sete montes como sete reis (96). Ainda no c:pítulo 17

(93). - Roger: "I es Religiors révéces", III, pä. 1t.

(91). - Loc. cit..

(95). - Pannier, art. "Eabylone" in "Dictionnaire de la Bible" de Vigou. reoux. Tai interpretasto do none "Fubilonia" nesta epistola foi aceita desde

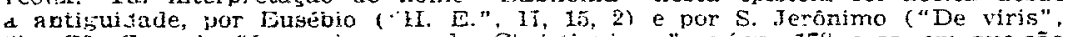
S) Cf. Griguel, "La hassance du Chrifisimr." pags. 17s e ss. em que são capostos os outros sistemas interpretitivos: MeNelle, op. cit.. pág. 212; Criaf.

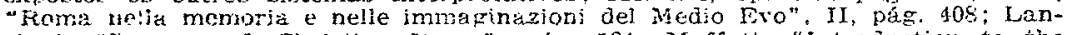
cieni, "Fagan and Christian. Fone". pas. 124; Moffatt, "Introduction to the

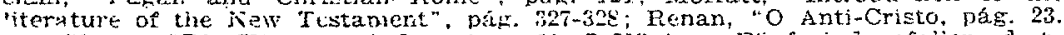
(46). - "Die Heupter sind rach $v$ io. $i$ Kunige. Funf sind gefalien, d. $n$. die julier vas Ausstus bis ivero. Jinc" ist gegenwirtigr d. h. (mit ibergebung des interconum), vespastal, Ler letzte ist noch nicht getommen, und wenn er lionmt, ist es inm bestimmt, nur eine burze Weile zu bleiben; gemeint jst Titus". (Nendland, "H. f. K.". päg. is), ct. Moffatt, op cit. pág. 600. - sto natualmente, deperde do ponio die vistu que se adote em relaça a epoca de composigāo do Apocaipsc; veja-se, por exempio, outra contagem dos reis.

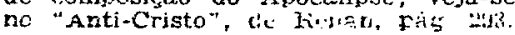


- próprio autor nos diz que a mulher "é a grande cidade que reina sôbre os reis da terra" (97), para em seguida rejubilar-se em virtude de sua destruição:

XVIII, 2 - "É caída, é caida a grande Babilônia, e é feita morada de demónios, e coito de todo o espirito imundo, e coito de tôda a ave imunda e aborrecivel.

3 - Porque tôdas as naçôes beberam do vinho da ira da sua fornicaçăo, e os reis da terra fornicaram com ela; e os mercadores da terra se enriqueceram da abundância de suas delicias.

7 - Quanto ela se glorificou, e em delicias esteve, tanto the dai de tormento e pranto; porque diz em seu coração: Estou assentada como rainha, e não sou viúva, e não verei pranto.

8 - Portanto num dia virăo as suas pragas; a morte, o pranto e a forme; e será queimada com fogo; porque é forte o Sentor Deus que a julga.

- 9 - E os reis da terra, que fornicaram com ela, e viveram em delicias, chorarão, e sôbre ela prantearão, quando virem o fumo do seu incêndio:

10 - Estando de longe pelo temor do seu tormento, dizendo: Ai! ai daquela grande Babilônia, aquela forte cidade! Pois numa hora velo $\rho$ seu juizo.

20 - Alegra-te sôbre ela, ó céu, e vós, santos apóstolos e profetas; porque já Deus julgou a vossa causa quanto a ela.

21 - E um forte anjo levantou uma pedra como uma grande mó, e lançou-a ao mar dizendo: Com igual impeto será lançada Babiônia, aquela grande cidade, e não será mais achada.." .

Trata-se, segundo Moffatt, de uma verdadeira estância de triunfo sôbre a queda de opressor, em que se descrevem os lamentos de reis e de mercadores, como o bem conhecido canto de Ezequiel sôbre a queda de Tiro. "As linhas finais retratam vivamente a repentine, viclenta e irrevcgável condenação da grandeza que fóra Roma (98)", simbolo do mundo, nova manifestação de Babilônia, corporificação da luxúria e do pecado, que tão nefasta fôra à cidade de Jerusalem e cujo nome, como expressão máxima da blasfèmia, achava-se inscrito na testa da mulher transportada pela besta (99).

E compreende-se bem que houvesse júbilo pela queda de $R a$ ma, uma vez que o Impéric Romano nada mais era do que o instrumento de Satã, do qual recebera o seu poder para blasfemar

(9i). - XVIi, is. Cf. Wendlund, op. loc. cit.

(98). - Op. cit., pág. 480̈, nota 1; páf. 488 , McNeile, op. cit., pág. 245.

(99), - Cf. Dousset. "Die Religjon", pág. 25" : Rebm, "Der Untergang Roms". vér. 21: Lebreton, "L'frice Primitive", vás. 247; Renan, op. cit., pás. 276 ss. Hornack, "Missione e propagazione del Cristianesimo nei prini tre secoli", pág. 39t, Sanford, "Contrastin's vews", pag. 443; Noffate, op. cit., pág. 488; Fisher. "The beginnings of Crristianity", pégs. 63, 534-535; Puech, "Histoire de la littérature Grecuuc Chrétienne." I, jä. 43T, n. 1 , que diz de maneira bastante Hara; "Il est manireste que la courtisane est Fome". 
contra Deus e pars fazer guerra aos santos, tendo o Anti-Cristo como seu aliado (100).

Acreditamos que o que foi visto revela à saciedade a manifestação do ódio a Roma por intermédio do Apocalipse. Ora, tal ódio só pode encontrar a sua expliçção nas relações entre Roma e o mundo judeu-cristão na época em que foi composto o referido livro; e chegamos, assim, ao exame da segunda questão que nos propuzemos a respeito daquele livro sagrado.

2 - Desde os primeiros tempes do Cristianismo já havia divergências a respeito da data à qual deveria ser atribuida a composição do Apocalipse, e ainda hoje tal questão dá margem a opiniões diverses, mas dentro de certos limites extremos; de fato, tais hipóteses variam entre o período de crise que se seguiu imediatamente ao govêrno de Nero (101) e a época de Adriano (102). Aliás, parece haver modernamente acentuada preferência pela época de Domiciano, sendo concordes neste ponto vários especialistas ne matéria, como Lebreton, Harnack, Wendland, Carluy, Moffatt e MeNeile (103); o último, depois de apontar os mais importantes autcres antigos que ercm favoráveis a êste ponto de vista (Iren, v. XXX. s; Eus. "H. E; III. 18; IV, 8, Victorinus, "In Apoc." X. II; XVII, 10), afirma categöricamente que "o livro, na sua forma completa, deve ser datado do reinado de Domiciano." O que há de interessante para nós nesta fixação da data é o que diz respeito à posição dos judeus e cristãos em face do Império nesta época. No lado judeu, temos sempre a luta, a resistência à romanização, como característica distintiva e assumindo o seu aspecto mais grave com a questão religiosa. Como já vimos anteriormente, vinha de longe a hostiliäade dos judeus a Roma, desde que os romanos apresentaram-se no mundo mediterrâneo como sucessores do domí-

(100). - Apoc, XIII, 4. CR. Wendland, "H. R. K.", pág. 252; Moffatt, op. st. páf. 487, Schmidt, "Lt probiène ou Christianisme primitif", pág. 95.

(1ii) - Ct. p. ex., Renan, op. cit. pág. 245 , que fixa mesmo o mês de janeiro de 69 jara a aparicaăo do livro: Roger, op. cit., III, pág. 14: Puech, "Histoire de la littérature Greogue Chrétienne", I, pag. 462 e ss.: "...peu de temps apres la crise epouvantable de l'an 69 , oú l'enpire Rumain parut si près ac se dissonare", păg. 466

(102). - Cf. Turmel, "L'Apocalypse", capitulos IV e $V$.

(103). - Lebreton, "L'Eglise trimitive", pág. 247; Harnack, "Missione e Propafazione", $p a g$. 196; Wendland, "If. R. K." pág. 382-383: Cariuy, art. cit.; Mommsen, "Das Weltreich der Caesaren", pág. 374: Goguel, "La naissance du Christianisme", pá̃s. 571, n. I $e$ is2; McNelle, op. cit., pág. 249; Moffatt.

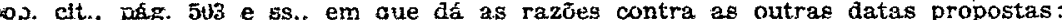
"The Neronic date (i.e. prior to the fall of Jerusalem and after Nero's mas-acre of the Roizan Christians) appeals especially to these who feel the dramatic situation of passages like $X I, I$ ss., and who decline to admit the use of 2ny sources. It is inandicapped, however, by (a) the phase of the Nero-redivizus myth whicis the apocalypses represents, and above all by (b) the fact that no worship of the elifueror, which is adequate to the data of the apocalypse, was enforced uxill Domitian's reign. The nypothesis of a date during Vespasían's reizn (so, e.g. B. Weiss, Dueterdieck, Bartlet: A.A., 388 f., C.A. Scott) svades (a) but not (b). Tespasian did not take his official divinity very seriously. "There is no record of any persecution during his reign; ... The Domitianic date thus offers a fair explanation of the epocalypse's references to the worship of the heast, in the light of contemporary history during the latter Jart of the first century. It is also in line with the earliest tradition, and miroborated by the internal evifence of the document itself". 
nio helenístico, e certos fatos, como por esemplo a expedição de Pompel e a profanação de templo por Cresso no ano 54 a. C. (104), haviam contribuido para agravar êste estado de cousas. $\mathrm{Na}$ época de César os fanáticos judeus resistiram, nas montanhas da Galliéia, ao regime imposto ao seu país, e as medidas de repressäo a qua Varus foi obrigado após a morte de Herodes mostravam bem qual era o sentimerito judeu em relação a Roma (105). Esta, por sua vez, correspondia de maneira semelhante a tal modo de sentir (106), e já com Tibério verificaram-se manifestações anti-semiticas por parte das autoridades imperiais, particularmente do prefeito do Pretório Sejano e de seu protegido Pilatos, êste último conhecido pelas ofensas que fêz aos Israelitas (107). O mesmo Tibério, entretanto, certamente conhecedor do fanatismo judeu, evitou qualquer conflito de ordem religiosa na Palestina e, durante todo o seu govêrno, respeitou as práticas tradicionais da religiãa e do culto de Israel. De qualquer modo, porém, era impossível conforme nota Lagrange (108) - que os judeus entressem no movimento de simpatia crescente, de relações mútuas agradáveis e-de reconhecimento pela ordem e pela paz que agrupava os outros conquistados no amor a Roma por meio de um sentimento de solidariedade; e a atitude de Calígula, que odiava os judeus (109) e que resolveu, não só perseguí-los, mas também impor-1hes o culto de sua própria pessoa divinizeda, tornou mais violento um entagonismo que sempre existira (110). Essa questão não se tornou ainda mais grave em virtude do assassínio do imperador, quando êste estava providenciando a erecção de sua estátua no próprio templo de Jerusalem, ameaça esta que teria repercutido entre os judeus de maneira mais intensa do que a perseguição desencadeada em Alexandria no ano 38 (111).

(104). - Cf. Winckler, "Die Juden und Rom", págs. 105 e 112 e ss.

(105). - Cf. Graetz, op. cit., II, págs. $77,115,123-125$.

(106). - "Quand on parcolirt les textes, où les auteurs grecs et romains parlent des Juifs, on est frappé de rencontrer chez la plupart un accent hostile ou defiant: antipathie ồ donine le inépris, ou tout au moins réserve iaquiete devant un peuple qu'os sent trop diffèrenti de soi-même..." (Bonsirven, "Le Judaisme. Fulestinien au temps de Jesus-Christ", I, pág. 3). Cf. Juster, op. cit.. 1, pág. $45 \mathrm{e}$ ss.: Guignebert, "La vie religieuse dans i'empire romain de Néron à Commode", págs. 14-15.

(107). - Tácito, "Anais", II, 85. "Suetônio, "Tiberio", 36; Josefo, "Ant.", XVIII, 3, 5. Cf. Graetz, "A History of the Jewe", II, pág. 130 e ss. Mommsen", "Das Weitreich der Caesarch", pas. 368; A. D. Nock e M. .P. Charlesworth, in "Cambriage Ancient History", $\bar{\lambda}$, păgs. 495 e 615; Juster, op. cit., I, pág. 224, n. 3; Finegan, "Light from the Ancient Past." pag. 218; Ricciocti, op. it., Il. nág. 431 e ss..

(108). - "Le Judaïsme avant Jsus-Christ", pág. 224.

(109). - Filo, leg. 20, ap. Mommsen, op. cit., pág. 370, n. 1; Graetz, op. sit., II, päg. 189 .

(110). - Caligula teria então sido comparado a Antíoco Epifanio, que permanecia sempre, para os judeus, o verdadeiro inodèlo da abominasão ("Urbil ner Grähel", sęundo Mommsen, op. cit., pág. 373), e éster fato, agindo numa ppoca em que as crenças messianicas atingium a um elevado grau de exaltação (Cf. Bousset, "Die Religion" "pA.r. 204), teria condicionado o aparecimento de um apocalipse, do qual encontrar-se iam elementos no proprio Apocalipse atriLuido a S. João (Eugène de Faye, "Les Apocalspses Juives", pp. $171 \mathrm{e}$ as. $\mathrm{kp}$ Moffatt. "An Introduction $t$ othe Literature of the New Testament", pá. 489. (1]i). - Monmsen, op. cit., pág. 372. 
A partir dai a ódio dos judeus para com cs romanos não cessou de progredir, apesar de algumes medidas de tolerância adotadas pelo Império, para explodir, por fim, na grande revolta de 66. A violência do levante anti-romano foi tão grande que levou Mommsen a afirmat que cal movimento inaugurou "uma nova era na história dos ódics nacion:is", uma vez que "a ambas as partes parecis impossivel a vida em comum, movendo-se judeus e romanos animados pela idéia do exterminio do adversário". Flávio Josefo deixcu-nos bem vivo o relato desta luta feroz, que só terminou plela quase destruição dos vencidos e pela decisão romana de suprimir o grande laço de coesão entre os judeus de todo o território imperial, ou seja, o seu centro religioso, juntamente com duas maiores autoridades: o grão-sacerdote e o Sanhedrin de Jerusalem. Os at sntados à religião tiveram ainda, como complemento, uma medida que lembraria permanentemente ao judeu o seu ódio a Roma: a transferêncie para Júpiter Capitolino e para seu representante na terra, que era o Imperador, da contribuição que até aí pagavam os judeus ao templo de Jerusalem. E' evidente, assim, que a atmosfera que envolvia as relações entre judeus e rom $=n o s$ na época em que a maioria dos autores coloce a composição do Apocalipse, isto é, no reinado de Domiciano, deveria ser bastante tensa, tanto mais quanto êste imperador, membro da família dos Flávios - que tão funesta fôra ao Judaísmo, - mostrcu-se grandemente rigoross na cobrança do didrạcma (112) e foi particularmente exigente na questäo da observância do culto imperial, a tal ponto que considerou como $\mathrm{o} \mathrm{m} \equiv$ ior dos crimes a recusa dêste culto por parte daqueles que, por motivo de ordem religiosa substancial, não podiam reconhecê-lo: os judeus e os cristãos (113). E nunca podemos nos esquecer de que o culto ao imperador era associado ao da Dea Roma, e que, portanto, o ódio votado às pretensões divinas imperiais envolvia témbém a própria cidade de Roma; tão importante era esta questão para os judeus e cristãos que não só justificaria os anátemas do Apocalipse, mas teria constituido mesmo a razão pela qual - referido livro teria sido composto, segundo o ponto de vista de Moffatt (114).

(112): - Suetơnio, "Domiciano", XII.

(113). - Gsell. "Essai sur le regne de lempereur Domitien", pág. 312. apud I dbreton, op.-cit., pág. 247, n. 3: Goguel, "La najsance du Christiansime", F.j.g. 575 .

(114). - Op. cit., pags. 508-509: "Over two centuries earlier the great exemllar of apocalyptic literaturc had been pubiished in order to nerve the faithful who were persecuted ror refusing to admit the presumptuous divine claims of Antioshus Eriphanes. John's ipor blyst is a latter-day pamphlet thrown up hy a similar crisis. The prophtet. believed that tie old conflict had revived in its final forro: Daniel predictions were on the way to be fuifilled when a Roman emperor biasplaemoasly claimed the title of "dominus et deus", and insigted on the rites of the Caesar-cultus as a test of loyalty. This popular deification iff the emperor, with the correspondin recoznition of "dea Roma", were parficularly ramiant in Asia Minor, and the apocalypse is a rigorous summons to the churet to rejudiate tie cuitus at all custs. Hence the emphasis upon tho "irtues of martyrdom and upon the speedy downfall of the Roman Empire". 
No que diz respeito ao elemento cristão, observa-se que suas relações com o Império não eram cordiais, nesta épaca. Em primeiro lugar, salta aos olhos que o. Cristianismo, surgido como se fôsse uma seita judaica, e apoiando-se na rêde de sinagogas para a realização de sua primeira fase expansionista, deveria também sofrer com o antisemitismo greco-romano, tanto $m=$ is quanto parece ter demorado algum tempo para que se fizesse bem clara, aos olhos dos pagãos, a diferença entre judeus e cristãos (115). Em segundo, havỉı a perseguição ñtoniana e, além disto, a ameaça constante que pesava sôbre os adeptos do Cristianismo, em virtude da existência da corrente tradicionalista romana que, renovada pelos esforços restauradores de Augusto e de seu círculo, devia ser permanentemente contra a infiltração de novas religiões no mundo romano e, portanto, contra o Cristianismo (116). Tratando do assunto, assim se expressa Lebreton: "A Igreja deve suportar não.mais sòmente \& hostilidade do mundo pagão, mas uma perseguição sangrenta: é por tôda a parte a luta entre o Cristo e o Anti-Cristo, os santos e a besta... Esta "grande tribuleção" (VII, 14-17), é a perseguição, desencadeada por Nero com ferocidade bárbara e retomada por Domiciano com ódio tenaz (117)". Acontece, entretanto, que - para o nosso caso - convém fazer uma distinção entre Nero e Domiciano: o primeiro parece não ter sido hostil aos judeus, por ter sofrido a influência dcs elementos introduzidos por Popéia no ćrculo imperial e que eram favoráveis ao Judaísmo (118). Tais elementcs teriam mesmo tido papel na decisão do imperador de perseguir os cristãos, considerados na época como integrantes de uma seita judaica (119). Já o segunđo foi contrário a juđeus e a cristãos (120), e a composição do Apocalipse de que tratamos durante o seu reinado dá boa margem à afirmativa da qualidade judeu-cristã de seu autor. Sem visır pròpriamente à perséguição neroniana, conforme afirma Mommsen (121), refutando a hipótese de Renzn no seu "AntiCristo", o Apocalipse tem como objetivo atacar a autoridade imperial que combatia, ąo mesmo tempo, os partidários das duas cren-

(115). - Que existia a confusäo na éoca de Claudio, parece evidente a muitos eutores que partem, para isto; da interpretação do famoso texto de Suetonio, "Clídio", 25 (Cf. Lebreton, op. cit,, pág. "u34; Mommsen, op. cit.. pág. 376, $n$. 1 ; Lanciani, "Pagan and Cirristian Rome", pas. 310; Homo. "Les empereure. romains et le Christianisme", pag. ag); ha margem para supor-se que o fato -permanecia :inda na éjoca de Domiciano (Cf. Lanciani, op. cit., pág. 6), e năo frita qucm afirme que durante o reinado de Trajano poderiam os romanos ver no Cristianismo apenas o desenvolvimento normal do Judásmo (Vesgereau. "Rutilius Namatianus", pag. 300), ou que permanecia a confusäo ainda sob Adriano (CF. Grautz, II. pág. 431).

(119). - Cr. Doissier, "La Fin du Faganisme", I, pág. 358.

(117). - Op. cit., págs. 246-247.

(IIS). - Cf. Josefo. "Ant." XVIII-IX; Túcito: "Anais", XIV, 16: "Histórias", I. 22. Cf. Lebreton, op. cit., pág. 290; Guignebert, "Lie Mionde Juif": pág. 23; Homo, "Les empereurs romains et le Christianisme", pág. w; Wendland,

"H.R.K.". pag. 249: Goguel, op. cit., pág. 5x6.

(119). - Lanciani, op. cit., pág. 312 : Lebreton, op. cif. pag. 292 ; Fishor.

"The beginnings of Cirristianity", páf. 520.

(120). - Lebreton, op. cit., pag. 292. e 301.

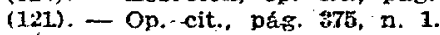


cas. E assim se explica que, por intermédio do Apocalipse atribuido a S. Joäo, os cristãos, que eram zinda em tão pequeno número, se "opuzessem ao imenso Império Romano e fizessem consistir na perseguição religiosa a principal ação dêste império e vissem nesta luta o término final de tôda a história humana"; é que se refletia ai - fato dá Igreja colocar-se a si mesma no lugar de Israel, adquirindo assim "consciência do fator político, destinado a exercer uma ação decisiva sôbre o futuro do Estado mundial e, por fim, a vencêlo (122)". Nestas condiçōes, o livro em questão estaria perfeitamente situado na. Jinha de seus antecessores, expressando o ódio nacional e religioso dos judeus contra os romanos, de tal modo que, na interessante frase de Wendland, "Pompeu, Calígula, Nero, fornecem o mcdêlo para o Anti-Cristo, Antíoco Epifânio redivivo (123)".

3 - Vista entắo a questão da data, podemos passar a ver o problemä referente à autoria do Apocalipse. Desde meados do séculọ II desenvolveu-se a tradição segundo a qual o autor teria sido o apóstolo Joz̃o, que escrevera também o quarto. Evangelho e a la. epístola que, sob o seu nome, foi acolhida no Novo Testamento (124). O primeiro a levantar dúvidas a êste respeito foi Dionísio de Alexandria, que não aceitou a atribuição do Apocalipse" ao apóstolo João que escreveu o Quarto Evangelho e a. "Epístola Católica" (isto é, I João) por 3 razões: (1) - o emprêgo feito pelo autcr do seu próprio nome, o que é evitado pelo evangelista; (2) - a diferença de idéias e pensamentos, e a ausência de alguns dêles que são marcadamente característicos do Evangelho; (3) - as excentricidades lingüísticas, barbarismos, solecismos, provincianismos, os quais faitam inteiramente no polido e fluente grego do Evangelho e da Epistola (125)."

A crítica moderna desenvolveu as objeçães de Dionísio, de modo e permitir que grande número de intérpretes afastasse completamente a hipótese da autoria apostólica (126). Mcdernamente, al-

(122). - Harnack, op. cit., págs. 146-197.

(123). - Op. cit. pág. 381.

(124). - C. McNeile, op. cit., pag. 250: "The tradition of the apostoilc authorship is met wits from the niudle of the second century. Justin Epeaks of the author as "one of the apostles of Christ" (Dial. 81: cf. Eus. H. E. IV. 18). Tert. (c. Marc. III. 14) "The apostle Tohn in the Apocalypse describes a sword proceeding from the nocth of God". Hippol. (Lagarde, p. 17) "Tell me, $O$ blessed John, apostle and disciple of the Lord, what didst thou see and hear concerning Babylon"" Orig. (in loan. tom. I, 14) "John the son of Zebedee gays in the Apocalypse". Victorinus (De fabric. mundi) "The angels ... who are called elders in the Apocalyse of John the apostle and evangelist". To these must be added irenaeus. who tinree times assigns the book to "John the disciple of the Lord" (TV. XX. 11, XXX. 4: V. XXVT. 1). This does not call him an apostle, but thoughout his pages he apyears to know (apart from John the Baptist) of no other .John than the son of Zebedee".

(125). - Mciveile, op. cit., pág. 251.

(156). - Goguel. op. cit., pág. 377 n. 1: "LApocalypse n'est pas sans préscrter ccrtaines affinités de langue et de pensé avec l'ivangile. Elles doivent, sans doute, $\varepsilon^{\prime}$ expiquer par le fait que toute la littérature jonannique a la méme origine geographique. L'urientation de la pensóe de l'Apucalypse est cependant fort différente de celle de l'ívangile et c'est, semble-t-il, la tradition que c'est constituee apres coup pour attribuer à des lives qui jouissaient. d'une autorité de fait une autorite de droit. qui a établi un lien entre l'Evangile et les épitrés d'une part. l'Apocálypse de l'autre, $\epsilon^{\prime}$ ieur donnant l'apótre Jean pour auteur 
guns vêm no Apocalipse obra de um só autor (127), outros consideram-no como produto do trabalho de mais de uma pessoa (128), mas parece que - apeser das divergências - há unanimidade em dois pontos, que são de grende importância para nós: a) - o livro foi composto por um palestiniano, portanto, em estreito contato com o Judaísmo (129); b) - a simples leitura do Apocalipse reyela a existência de enorme quantidade de elementes judaicos, o que permitiu até mesmo o lançamento da hipótese segundo as qual tratar-se-ia de um apocalipse judeu em versão cristã (130).

Teremos assim, sempre, na origem da obra em questão, "um autor que vive na atmosfera de imaginação do Antigo Testamento, particularmente dos profetas e da apocalíptica judaica (131)", que odeie Roma e que considera a punição da cidade como condição indispensável para que se instale o Reino do Messias (132).

O. Apocalipse pode ser considerado como o último grande testemunho da atitude comum de judeus e de cristãos contra Roma, documento surgido num periodo em que os dois elementos, "vítimas da fôtça, haviam confiado a Deus a missão de vingá-lcs, esperando com confiença inabalável o dia anunciado por seus profetas, em que seus inimigos deviam ser exterminados"; tais palavras, do tão con-

commun". Cf. Maveile, op. cit., päg. 251-252; Puech, op. cit., I, pág. 465; Moffat, op. cit., pág. 509 ss.; Charles, "A Critical and exegetical commentary on the Revelation of St. John ${ }^{r}$, ap. Gry, in Révue Biblique, Tomo XXXI, 3922, jág. 292-302. Outros, entretanto, defendem o ponto de vista fevorável ao apóstolo Joâo; cf. por exemplo, Bardy, "L'eglise a la fin du premier siecle", pág. 14: Allo, "Apocalypse", cap. 13 da introduç̄o, págs. CLXXXViIl-CCXXXII, ap. Lebreton, "L'Élise primitive", pág. 246. n. 1; e o próprio Lebreton, que assim se expressa: "... l'Apocalypse, l'Evangile, les épitres johanniques... En ce proplète, en cet evangeliste nous reconnaissons l'apôtre Jean, et le témoignage des livres eux-mémes est eclairé et soutenu para une tradition très ancienne et bien garantie".

$(127)$. - Naturalmente, todus os que aceitam a autoria do apóstolo: entre os qun nāo a aceitam, podernos citar, por exemplo, McNeile, op. cit., pág. 253 e Moffatt, op. cit., pág. 513, favorável à autoria de João-o-Presbitero.

(128) - - Sf., por exemplo, Charies, ap. Gry, op. cit., para o qual o autor do Apocalipse nào póde termina-10, encarretando-se desta tarefa um de seus discipulos, ao qual caberia, alíx, grande responsabilidade pelos problemas que o Ijvro oferece $\hat{a}$ interpretação, como se ve: "...profundamente estúpido e ignorante, fanático estreito e celibatário, nem sempre leal na sua missão de editor. herético consumado, ainda que se considerando a sua estupidez, era provàvelmente inconsciente" (pág. XVIII). Tal ajiscipulo e que teria modificado ou interpolado vários versos, deslocado senteņ̧as, enfim, teria feito. de um "livro claro e coerente, a obra obscura que tem perturbado os críticos".

(129). - McNeile, op. cit., pag. 253; Charies, ap. Gry, op. cit ; Harnack. "Missione e prupagazione", pás. 560; Puech, op. cit., I, pág. 465; Moffatt, op. cit., pág. 513 .

(130). - Trata-se da hipótese apoiada por Vischer ("Die Offenbarung Johannes eine jüdische Apk. in christlicher Dearbeitung") e outros intérpretes; Cf. Moffatt, op. cit., pág. 490 ; Puech, op. cit., $Y$, pág. 444-415, 447 ss. en que trata da participaçăo dos elementos judaicos no Apocalipse atribuido a João, "soma da literatura apocaliptica". Cf. ainda Charles, ap. Gry, op. cit.; Gry. "Les chapitres XI e XII de I"Apocalypse", in "Révue Biblique", tomo XXXI, 1922, págs. 203-214; Moffatt, op. cit., pág. "48s e ss. em que há um elucidativo suríario da critica das fontes do Apocalipse. Há também quem dê ao referido livro uni caräter acentuadamente judaico; ef. Turmel, "L'Apocalypse". págs. 15 e ss.. para o qual tratar-se-ia de obra dos judeus, notivada pela revolta verificada nú epoca de Adriano.

(131). - Bousset, "Die Religion deg Judentums in nuetestamentlichen Zeitalter", pág. 139, an. Wendland, "I. K.K.", pág. 383.

(132). - "Livre da presenca da grande prostituta (Roma) a terra está pronta para o himcneu celeste, para o reino do Messias" (Renan, "O Anti-Criato". rág. 300. Cf. Apoc., cap. XIX). 
cituado Boissier (133), encontram seu maior apôio num versiculo do Apccalipse, no qual se manifesta de maneira bem clara a esperznça, que já encontramos em obras congêneres, de castigo divino sôbre a potência opressora:

"Até quando. ó Dominador e santo. verdadeiro, não julgas e vingas o nosso sangue dos que habitam sôbre a terra?" (134).

A partir da época da composição do Apocalipse, como se sabe, foram se desenvolvendo cada vez mais as conseqüências de dois grandes fatos: primeiramente, a própria destruição do templo (135) e a atitude dos cristãos durante a guerra judaica, afastando-se dos judeus e atraindo a si a ira da literatura $\mathrm{r}$ r bínica e das sinagogas (136); e em segundo lugar, como veremos, os efeitos da predicação de S. Paulo, desligando completamente o Cristianismo do Jưaaísmo e dando-lhe muito maicr amplitude. Isto não quer dizer que, desligados do Juđaísmc, os cristãos tenham abandonado imediatamente os seus ataques a Roma; mas julgamcs não ser por mera coincidência que as produçōes dêste tipo tenham sido sempre inspirades por fontes judáicas, como já vimos aliás, com os Sibilinos judeu-cristãos e como se verifica também com a obra do primeiro poeta 1Etino-cristão conhecido, ou seja, Comodiano.

Assim como o sibilista parte dos oráculos judeus, o poeta inspira-se na literatura apocalíptica, no seu mais amplo sentido (137), tratando, no "Carmen Apologeticum", dos mesmes assuntos a que já nos temos referido, como, por exemplo, o julgamento universal e o fim do mundo. Há ainda muito de obscuro a respeito de Comodiano (138), mas não deixa de ser interessante que, antes de se ter a África como sua pátria mais provável, admitia-se ser êle originérió de Gaza, na Palestina e, portinto, da própria região central do Judaísmo (139). Parece-nos que não será absurdo esta-

\footnotetext{
(133). - "La Fin du Paganisme", II, jäs. 24.

(134), - Apocalipse, VI, in.

(135). - Os dois fatos, alís, ligam-ge perfeitamente. Cf. Mommsen, op. cit., Dág. $39 x$.

(136). - Lebreton op. cit. pár. 243.

(137). - Lezreton, "De la Fin du $2 . e^{e}$ siecle a la Paix Constantinienne", pág. 3k1: Labriole. "Histcire de la littérature latine chrétienne", pág. 243.

(138). - A comeacr pela epoca em que viveu: Ebert. Boissier e Labriolle situin-no na 2." metade do século lil; Larnack, entre 260 e 350; Kraus, no ińcio do seculo TV: Mass na 2." metade do seculo IV; Brever e Drüsele, no sevio $y$ (Ap. Labriolie, op. cit. pig. $246 \mathrm{ss}$ ) ; optando tamberm pelo seculo $\gamma$ sncontra-se, recentemunte: $P$. de Courcelle, "Histoire littéraire des grandes invasions germaniçues", págs. IN- -130 ).

(139). - Tal presumeão baseava-se em que a ültina peca das "Instructiones" intitula-se "O nome do homem de Gaza", formando. no acróstico. a frase "Commodianus mendicue Chriat" (Boissier, "La Fin du Pamanisme", II, pág. 2S). Para Bardenhewet encontrar-se-ia ai um verdadeiro enigna: "Der Name "Gaseus" aber entrijit ein schwer zu lüsendes Rätsel. Man pflegt Gaseus einem Gazaeug : eichzusctzen und Gazaeus entweder auf die Heimat des Dichters zu deuten oder als eine tbersetzung bzh. Nachbildung des Namens kommodianus aufzu-

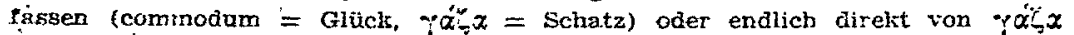
- Schatz berzuleiten. Auf diesem letzteren Fiege ist man zu der tbersetzung "Eesitzer eives grossen Schatzes" (des Schatzes der wahrheit nämlich, welchen np Dichter in Chrigtentum zefunden habe), anderseits seltsamerweise aber ouch
} 
belecermos a relação entre a grande influência judia scfrida pelo autor e a tendência a localizar sua origem na Palestina, havendo mesmo quem, como Ebert, emita a opinião de que "á julgar-se pelas aparências, fci êle, a princípio, um prosélito dos judeus (140)".

$\mathrm{Na}$ verdade, encontramos em Comodiano o mesmo rancor dos israelitas contra Roma, e com a mesma ênfase apocaliptica, como se pode.particularmente vêr pela última perte do poema; aí notam-se trachos bastante significativos, "que traduzem os mais violentos sentimentos de ódio causados pelo mundo antigo (141)", como o seguinte:

"Que desapareça para sempre êste império onde reinava a iniqüidade, que, pelos tributos que por tôda a parte levantava sem piedade, fizera emagrecer o mundo..." "Ela (Roma) chora por tôda a eternidade, ela, que se jactava de ser eterna (142)."

A semelhança com os orảculos judeu-christãos é notável na passagem dos tributos, particularmente na referência à cupidez romana (143), e o mesmo contato transparece em cutros trechos; como naquele em que, após tratar do segundo Anti-Cristo, Belial, que accibaria por destruit a própria Roma, o autor prevê a sua derrota pelo "povo dos Justos", resto das tribos fiéis, mantido em reserva por Deus (14); parece-nos claro que, imediatamente, tais linhas evocam-nos c. livro VIII dos oráculos, nos seus versos 140-141.

Comodiano, entretanto, deve ainda preocupar-nos aqui por dois aspectos dignos de nota: em primeiro lugar porque, ao mesmo tempo que ztaca os pagãos, volta-se êle também contra os judeus, nas suas "Instructiones" (145); e em segundo, palo seu pouco contato com a cuitura clássica e pela sua animadversão em relação a esta, - que é admitido unânimemente pelos autcres por nós consultados. Aliás, podemos adiantar que Genádio, por exemplo, trata de Comodiano em têrmos bem pouco lisonjeiros: "Scripsit madiocri sermone quasi verso (146)". Este último traço, principalmente, parece-nos

zu der tbersetzung "ein aus den: inirchenschatze Unterstiitzer" gelangt. Das Natürlichste bleibt es Jedenfalls, unter Gazaeus einem Mana aus Gaza zu verstehen, und am nüchsten liegt es ohne Frage, an Gaza in Palästina zu denken". "Geschichte der altkirchlichen Literatur", II, pág. 555).

A favor diz África como vátria do poeta, cf. Lebreton. "De la fin du 2." siecle à la Paix Constantinienne". pag. 379; Raby, "A History of Latin-Christian joetry", pág. 12; Monceaux, "Histoire de la littérature latine chrétienne", pág. 73. (110). - "Histoire générale de la littérature du Mosen Áge en Occident". I, pág. 101; Bardenhever, o!s. cit., if, jág. 5St̃.

(141). - Picion, "Histoire de la litterature latı́ne", pág. 78T.

(142). - Carmer, 923-2, 58 e 580, ap. Bolssier. "La Fin du Paganisme", II, pág. B́.

(113). - Ja no seculo III os cristĩos louvavain a Pax Romana (cf. Tertliliano), e não combatiam-na por motivos financeiros. Isto era muito mais próprio aus judeus, e aqui Comediano assemelha-se muito mais a êles do que aos sristäos; alidis, cm muitos pontos, cono vimos.

(11i). - Cr. Eoissier, "La Fin du Paganisme", II, pág. $3 \overline{0}$

(145). - Por exemplo, I, 34. Cf. Eoissier, II, pág. 32 ; Pichón, op. cit., pág. șí-875.

(146). - "De Viris illustribus", XT, ap. Lebreton, "De la' fin du 2. Giècle a la Paix Constaninienne", pijz. 3Se, c. 2 ; Cf. Labriolie, op. cit., páz. 235. Nota-se também, que $S$. Jeronimo nāo o inclui ao seu "De Viris". 
justificar o fato de que nos tenhamos ocupado de Comodiano logo depcis do Apocalipse, apesar de diferença de tempo que medeia entre os dois. E' que aqui, em se tratando da idéias, o fator tempo. passa a ter uma importância secundária: Comodiano, situado pelo menos no III século, está como q̨ue ctrazado em relação à sua época, prendendo-se mais ao Apccalipse do que a autores cristãos do tipo de Tertuliano cu Latâncio. Estes, vivendo num ambiente de perseguição aos cristăos, o que seria uma justificativa razoável para a. expressão do ódio a Roma, são muito cuidedosos nos seus contraataques; se fazem alusôes ao castigo que puderá cair sôbre a cidade, fazem-no com grande discreção (147), ou desviam os seus ataques para os imperadores, poupendo a cidade que logo deveria ser louvađa, e não condenada pelos cristáos.

Quer nos parecer que Comodiano é o último autor cristão a combater a cidade de Roma à maneira juđia, e já vimos em que condiçōes. Quanto aos judeus, suas invectives à cidade não cessaram, desenvclvendo-se ainda sob a forma de literatura apocalíptica, como se pode ver pelo IV livro de Esdras e pelo Apocalipse siríaco de Baruch (148). Tomando-se o IV Esdras e considerando-se as duas dat $=6$ extremas que sáo supostas como assinalando a sua composição, isto $\dot{e}$, as de 95 (Eproximadamente) e de 120 , encontźá-las-emos em períadcs de real significação para as relações entre os judeus e Roma: a primeira, em pleno govêrno de Domiciano, do perseguidor e cúpido adversário do Judaísmo; a segundz, logo após a morte de Trajano, num momento em que os judeus acabavam de lançar uma cartada de grande responsabilidade no seu jogo anti-romeno, com. aquela rebelião tão enèrgicamente reprimida pelos delegados imperiais. Assim, num e noutro cáso, o ambiente se mostra favorável ao aparecimento de apccalipses. A mesma couss se observa $\mathrm{com}$ o Apocalipse siriaco de Baruch (cu II Baruch): se optarmos pela data que Renan propõe, cairemos no mesmo caso antericr; se pela fixada por Charles para sua redação final, ver-nos-emos entre os anos 50 e 90 e, portanto, na época da grande rebelião de Jerusalem sob

(14\%). - CE., por exemplo, Tertuliaro, "Apologetica", XXXIr, 1; S. Cipriano, ad Demetriandim, AXI; Latancio, com seu trabaho "De mortiłus persecutorum". C1'. Lubriolle, "Histoire de la littérature latine chrétienne", pág. 241, n. 3.

(148). - Corno acontece E*lalmente com tais abras, há divergéncias quanto A data da composigão, o que, aliảs, não é de grande interésse para nós, uma vez que todiss as datis propostas estao dentro do período de que tratamos. Para Thenan o IV Esdras precederia o de Baruch, datando de 97 ("L"Apocalypse de

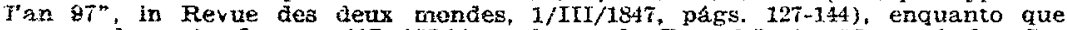
o segundo seria do ano 117 ("L'Apocalypse de Baruch", in "Journal des Savants", 18T1, pags. 222-231, an. Batifoll, art. "Apocalypses apocryphes", in "Dictionnaire de la Bible" de Vigouroux); já para outros, assim como Charles ("Religious developerent between the old and the new Testaments", pags. 242 ss.) e Sigwalt "Die Chronologie der syrigchen Barucluapocalvpse, in "Pibl. Zeitschr." 9 (1911) 397 e 38. e "Die Chronologie des 4. Buches Estas", in "Bibl. Zeitschr." (1911). pág. 16t-8, ap. Christ, "Geschichte der griechischen Literatur", II, págs. Fin. $n$. 1 e 58., n. 1), tal ordem deve ser invertida, ficando o de Baruch na segunda metade do século I (ano 82, para Sigwalt) e o de Esaras em 120, para Charles, e em 100, para Sigwait. Veja-se tambérn, para a questão da data, as introducoses aos referidos livros in Kautzasch, "Die Apokryphen und Pseudocpigraphen des Aiten Testarients", pags. -352 e 407 . 
Nero e Vespasiano (149). De qualquer maneira, então, teremos. sempre momentcs de grande importância para o povo judeu, e sempre situações semelhantes às que, sob Antioco IV, condicionaram o aparecimento do primeiro apocalipse. Não é de admirar, assim, que - livro de Daniel seja tcmando pelos autores do livro de Baruch e do IV Esdras, reaparecendo na propaganda: anti-romana os mesmos temas da propaganda anti-selêucida: a divisão da História em períodos designados por impérios correspondentes a uma degradação e a destruição do último, marcando o início de uma era de felicidade para os judeus. O IV Esdras é mesmo o primeiro documento em que se interpreta o episódio do sonho Nabucodonosor com aplicação a Roma (150), mas sem que isto signifique que só na época da composição dêste livro tivesse surgido tal idéia; aliás, é exatamente - contrário o que nos dizem Strack e Billerbeck, apoiados pela autoridade de Linder: "se o autor do IV Esdras é o primeiro de que temos notícia a explicar o quarto império de Daniel como sendo Roma, isto não quer dizer que tenha a primazia desta interpretação. Esta é muito mais antiga. Pode-se dizer, com segurança, que nos últimos quarenta anos de existência do Templo não havia judeu algum que não visse no Impéric Romano o último império mundial inimigo de Deus (151)." E IV Esdras, adotando êste ponto de vista comum dominante extre os israelitas, abre-se então numa série de imprecaçóes contra a cidade pecadora, a Babilônia prestes a cair :

"Tu reinaste sóbre o mundo pelo terror e não pela verdade. Tu esmagaste os homens doces, tu perseguiste os gue amavam a paz, odiaste os justos, amaste os mentirosos, humilhaste as muralhas daqueles que não te haviam feito mal algum. Tuas violências subiram até o trono do Eterno, e teu orgulho chegou até o Todo-Poderoso. O Altissimo consultou então o quadro dos tempos a viu que a medida estava cheia, que seu momento havia chegado. Por isto tu vais desaparecer, tu, ó águia, e tuas asas horriveis, e tuas aguazinhas malditas, e tuas cabeças perversas. e tuas unhas detestáveis, e todo o teu corpo sinistro, a fim de que a terra possa respirar.... (152): :

A mesma idéia dos impérios, de sua đegradação e de Roma como o último dêles encontra-se no Apocalipse siriaco de Baruch (153), que profetiza a ruína de Roma pelo fogo e sua ocupação pe-

(149). - Charles, op. cit, pág. 244; Cf. Sanford, "Contrasting views", p.ig. 448 .

(17̃0). - IV Esaras, 12, 11; cf. Bousset, "Die Religton", pag. 218.

(151). - "Kommentar zum Neuen Testament aus Tolmud und Midrasch" IT, 2, pág. 1002, ap. Linder, "Conmentarius in Librum Daniel", pág. 155, n. 1. E interessante que o autor do IV Esdras refere-se mesmo a Daniel em termos que mostram a sua importancia conlo modêlo para os israelitas que quisessem. manter-se fiés ao Judásmo. (CP. XIV, 4, 20; XXVIII. 3 ).

(152). - Ap. Renan, "L'Apocalypse de l'an 97", pag. 140.

(153). - 39, 3 e ss.: ". .virä dias en que este reino, que outroira destruiu zion, sera também destruido por equêle que vier após ele. Mas mais tarde, timbém êste, apßs algum tempo, serḱ destruido e surgira um outro, o terceiro. F Este também, na sua época, apoderar-se-a áo domínio e depois sera destruido. 
los demônios, enquento caberá a Jerusalem regozijar-se pela reuniāo de tcdos os seus filhos dispersos; terá então início o reinado do Messias.

A grande rebelião judia durante o govêrno de Adriano (154), colocada sob a chefia espiritual do rabino Aquiba, é, por si só, urn testemunho da hostilidade judia a Roma, mas - ccmo sempre a luta se processou não sòmente no campo material mas também no espiritual; daí a participação de Aquiba pcr meio de escritos, não faltando mesmo quem ligue a êste rabino o próprio. Apocalipse siríaco de Baruch, bem como a "Assunção de Moisés", obra compósita de caráter apocaliptico em que témbém se encontram amargas referências zo dominio romano e expressōes de esperanças na justiça divina (155).

A partir de 135, data da dispersão definitiva dos judeus em virtude de sua derrota e da terrivel repressão exercida pelos romanos (156), o ataque a Roma passou a ser um traço comum na sua literatura, particularmente na' produção rabínica, rica $\mathrm{em}$ cálculos sôbre o fim de Roma e em alusões à opressão rcmana. "A justiça romana era louvada, mas odiada a capacidade de seus venais júzes. A cidade de Roma, seus eđifícios, riquezas e tradições eram admirados, mas sua vida social era condenada e os romanos, em geral, eram ccnsiderados avarentos e ambicioscs, legítimos represen-

E depois levantar-se-a o quarto reino, cujo dominio será pior e mais duro do Guc o dus outros, que existiram antes dèle; e governará durante muito tempo, como a ilupesta a planicie. e manterá pur muiro tempo a supremacia e levantarse- $a$ rais allo do que os cedros do Libano. E nele deverá estar ocultáa a ver. lade, e para ele fugirão todus os que por crines estiverem maculados, do mesmo modo como os animais selvagens fogem para a floresta e no seu seio st - resugram. E quando chegar a epoca do seu fim, para que tle caia, então revelar-ae-ä o doranio do mea Mesias, que se assemelha à fonte e a cepa da viTrira"

(1); ). - Cf. Graetz, "A History of the Jews". Il, pág. 407 ss.; Juster, "Les Juits ủans l'empire liomain", II, jág. 190 e ss.; Licciotti, "Histoire 2.jsrael", II, pág. 5TU ss. Quanto a Auuiba, enorme foi o seu prestigio entre os judeus, podendo rivalisar neste ponto con o proprio hioisés (Cf. Simon, "Verua

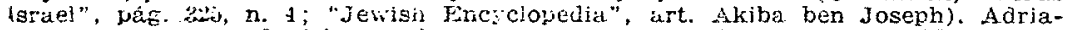
no. por sua rez, adquiriu um lugar particularnente importante no odio judeu, 0 que se reflete até em documenios ben posteriores ao século II, como por cxemplo, no "tutin Rabbi", euja conposicano pirece poder localizar-se no seculo YJ (Cf. Flieg, "Anthologie Juive", I, pág. 210).

(15i). - Grunde núnero de inturpretes coloca o aparecimento deste livro Aurnate o sécule I (cf. Jialicksch, op. cit., jadg. 313), mus nāo há unanimidade a respeito, como se vê pela seguinte passagem: "Die Erzählung führt bis in rie Zijt nach dem Tode des Herodes des Grossen; in diese Zeit haben die meisten Forscher auch die Entstehung der Schrift veriegt (IR. H. Charles, zwischen 7 und 3 (t n. Chr.). Aber dieser Ansalz kann kium mehr aufrecht ernalten wer-

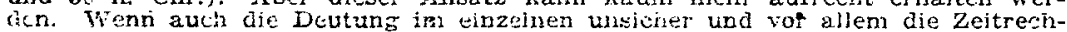
wung des Verfissess sciwer zu deuten iat, so weisen doch manche spuren in die zeit Hadrians und das Jahr 141 oder $13 \%$ wird als Entstehungsjahr anzuthmer sein". (Christ, op. cit... II, paig. 5sil). Rosentival ("Vier apokryphische Bücoer aus der Zeit und Schuie R. Akibas", Berlin, 18Sĩ), expressou a opiniño dc que a "Assunçăo de Moisés", assim como II Baruch e $W$ Esdras foram devirios a escola de Aquiba: cf. Chisres, "Relimious development", pág. 244, $n$. 1 . gue conkate esta biriútese.

Quanto aos trechos deste liwo que interesam ao nosso assunto, são êles VI, R.9 $E \mathrm{X}, 8-10$ (Cf. Giover, "The conflict of religions in the early Roman EmDire", pás. 170-171\}.

- A respeito da "Assungão de Moises". em geral, cf. Lagrange, "Le Juđaïsmạa "zizart Iésus-Christ", pág. 237 e ss..

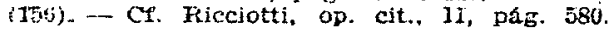


tantes de uma "Idade do Ferro". Em geral, a teoria do Império era considerada admirável, mas desprezível a sua prática (157)".

$\mathrm{E}$ a imagem dos quatro impérios de Daniel continuou a servir aos judeus para o anúncio do fim de Roma como o último dos impérios; é o que se verifica, por exemplo, no comentário rabínico "Mechiltha in librum Exodi", do século II, no "Targum Ps. Jonathani, ad Habacuc", além de muitos outros que, coligidos por Strack e Billerbeck, mostram ser êsse um ponto de vista ccmum aos judeus. (158).

Acreditamos, em vista do que foi dito, poder-se fixar de maneira clara a diferença entre o eparecimento de Comodiano entre os. cristācs, como anti-romano, e tôda a literatura judia do mesmo tipo. O primeiro representa um fenômeno esporádico, de cuja legítima formação cristã pode-se duvidar em muitos pontos, e que chegou a não ser aceito pelos próprios cristãos (159); quendo muito, representaria êle um sentimento pcpular (160) de hostilidade a Roma em virtude das perseguições, e que não estaria em condições de compreender o alcance da altitude dos legítimos $r \in$ presentant $\varepsilon s$ do pensamento cristão, atitude essa bem diversa, como veremos. A segunda, é a expr cssão de uma linina de conduta normal ac Judaísmo, a tal ponto que, depois do ano 70, a propaganda anti-romana e as esperanças da restauração de Zion tornaram-se um lugar comum na: literatura judia (161). Os cristãos, entretanto, não acompanharam esta tendência, o que nos leva a podar afirmar que os grandes fatos. que dissociaram o Cristianismo do Judaísmo marcaram também $\odot$ início de uma mudança de atitude dos cristãos em relação a Roma er certamente. - Essinalaram o primeiro grande passo na aproximação Igreja-Império.

\title{
(Continua no próximo número)
}

\author{
PEDRO MOACYR CAMPOS \\ Livre-docente e assistente da Cadeira de História \\ da Civilizagão Antiga e Medieval (U.S.P.).
}

(157). - M. Hadas, "Roman allusions in Rabbinical Literature", in Phil. Quart., VIII (1929\%, págs. 370-3\$6, as. Sanford, op. cit., pág. 449. Bousset, "Dic Religion", págs. 216-217:- "Selbst in späteren Jahrhunderten war an der eigentlich messianiscien Hoffnung dies die Hauptsache: die Umkehrung aller Machtvernidinisse. Isiael muss zu seinem Rechte kommen sein ${ }^{n}$. No século $V$ os ciaculos sibilinos eram plenamente divalgados pelo Mediterrâneo, como se infere do que se le na "Cidade de Deus" de Sto. Agostinho, XVII, 23.

(15i). - Cf. "Kommentar zum Nieuen Testament aus Taimud und Midrasch". IT, 39:, IV, pass. 858, 10ư2, 1001, 1203. Alé1n disto, notam-se ainda os seguintes exemplos de sentimento anti-romaro: Roma comparada 20 porco, III, 393, 304: loma como adrersária do Miessias, TV, 873 , 875; Deus castigando Roma, III, 823, IV, \$58, 862: previsẽo da queda soure Rona das pragas que assolaram o figito, ill, bls. Cf. Linder, op. cit., págs. 155-156.

(159). - Rand, in "Cambridge Ancient History", XII, pag. 605.

(16u). - Sonre sua propria urigem plebéia. Cf. Lebreton, "De la fin du 2.0 siecie ì la Paix Constantinienne", piz. 37 . o estado de sua linguagem parece demonsíar támben: que escreveu' para o elemento popular; cf. Devuto, "Storia dclla lingua di Rowa", paig. 323; Amutucci, "La letteratura di Roma Imperiale", pég. 177; ilonceaux, op. cit. pág. 74.

(161). - Charles, "Religious developinent", pág. 244, n. 1. 